\title{
New Indicators of Related Diversification Applied to Smart Specialization in European Regions
}

\author{
Artur Santoalha ${ }^{*+}$
}

\section{December 2018}

\begin{abstract}
This paper proposes two new indicators of related diversification applied to Smart Specialization. The indicators are useful monitoring tools to assess the initial conditions and evolution of the European regions (NUTS 2) regarding one of the orienting principles of Smart Specialization: relatedness. The first indicator ranks regions quantitatively in a given year concerning related variety of specializations; the second one captures to what extent regions acquire, over time, new specializations in related areas. These indexes use the concept of technological relatedness, and are applied to the case of European regions using the OECD REGPAT database. The results indicate that regions located at the core of the European continent, as well as Northern European regions, perform better, whereas Southern and Eastern Europe persistently exhibit lower scores.
\end{abstract}

Key words: smart specialization, related diversification, patents, European regions

JEL codes: O33 R58

\footnotetext{
* University of Oslo - Centre for Technology, Innovation and Culture - P.O. box 1108, Blindern 0317 Oslo Email address - artur.santoalha@tik.uio.no

${ }^{+}$I would like to thank my supervisor, Fulvio Castellacci, for guidance, help and advice with this paper. His comments have significantly improved the quality of the manuscript. I would also like to thank Francesco Di Comite for detailed and helpful comments. Further, my thanks go to Dominique Foray, Eric Iversen, Christine Mee Lie and Gianluca Orsatti for comments on earlier versions of the paper. Needless to say, responsibility for any remaining errors and shortcomings is mine alone.
} 


\section{Introduction}

The policy concept known as S3 (Smart Specialization) has become increasingly important (Foray, David \& Hall, 2011). However, an accepted framework for quantitatively measuring this concept seems to be lacking. According to Foray et al. (2011), S3 is 'a perfect example of "policy running ahead of theory" (Foray et al., 2011, p. 1) - policy-makers are already developing policy initiatives towards S3, without the tools necessary for measuring it or understanding it in terms of theory. The absence of such a framework constitutes a gap that this article seeks to close, at least in part.

In a recent work, Balland and colleagues propose a framework for the S3. This policy concept concerns developing new specializations (thus the term 'specialization'), in harmony with the local capabilities existing within each region (thus the term 'smart'). Taking this framework of analysis as their point of departure, Balland, Boschma, Crespo \& Rigby (2018) associate S3 with the emergence of new specializations, in technologies, industries, or other regional capabilities. Basically, a connection is established between the concept of S3 and the idea of related variety at the regional level. Boschma \& Gianelle (2014) have also defended a similar idea.

However, the relatedness concept does not appear to have been used for quantitatively ranking regions in terms of their diversification performance in the context of S3. This article utilizes various indicators for capturing the extent to which diversification in European regions is following the principle of relatedness, embedded in the concept of S3. First, an indicator is developed to measure the status of selected regions in terms of diversity, and to what extent the existing pattern of regional variety is in line with the principles of relatedness underlying S3. Then, the article also proposes an index to explain how diversification, according to the principles of S3, has evolved over time for a given set of regions (NUTS 2), also using the concept of relatedness.

Indicators are tested by means of data on patents from the OECD REGPAT database. This yields an analytical framework based on the technological relatedness approach, as the analysis proceeds with the different technologies underlying each type of patents. Compared to other existing relatedness indicators, these indexes are developed to be useful monitoring tools assessing the initial conditions and evolution of the European regions regarding one of the orienting principles of Smart Specialization: relatedness. The methodology adopted here proposes regional vertical prioritization of all technological domains, according to their 
potential for regional embeddedness (in the technological structure of the regions). Based on this and on the actual regional technological specializations, the proposed indicators measure, both statically and dynamically, the performance of European regions concerning technological relatedness. Indicators are computed considering the contemporaneous technological structure of the regions, which maximizes the usefulness of the proposed indexes as regional monitoring tools.

This paper has a threefold purpose: to contribute to the literature on S3 by proposing new indicators for measuring the technological dimension of this concept; secondly, to test these indicators, using the OECD REGPAT database; and thirdly, to provide, for the first time, a ranking of European regions in terms of technological relatedness applied to S3, showing how different territories stand and how they have been evolving. Section 2 presents the concept of $\mathrm{S} 3$ and the reasons for quantitatively measuring it, as well as why the concept of relatedness is deemed appropriate for this. The datasets are discussed in section 3, while section 4 presents the empirical strategy - methodology and indicators. Main results are presented in section 5. Section 6 discusses few caveats related to the delineation of the data in terms of time-periods, regions, and technologies. Section 7 offers some conclusions.

\section{S3 and related diversification}

\subsection{S3 - The concept of S3}

$\mathrm{S} 3$ is an approach to innovation policies that aims at prioritizing $\mathrm{R} \& \mathrm{D}$ and innovation projects in those activities where they are more advantageous for a given territory (Foray et al., 2009). This policy is based on 'the simple idea that i) regions cannot do everything in science, technology and innovation and ii) they should promote what should make their knowledge base unique and superior' (Foray et al., 2011, p. 3). With such an approach, this policy necessarily targets the promotion of certain activities, technological fields, and even industries, at the expense of others (vertical prioritization). For this reason, Foray et al. (2011) argue that the S3 approach towards regional development differs radically from common practice otherwise, which is mainly based on horizontal policy measures targeting the overall framework where various economic agents are involved. Also new with this policy concept is the adoption of place-based policies, in contrast to 'one-size-fits all' approaches (Moodysson, Trippl \& Zukauskaite, 2015). 
Achieving consensus as to how regions should delineate their S3 strategies (and then operationalize vertical prioritization) is difficult. While some have argued that the process should be the outcome of a bottom-up approach (Foray, 2013; Camagni and Capello, 2013; Boschma, 2014), others maintain that, especially in small and non-specialized regions, it should be led top-down (Iacobucci, 2014). In the latter case, regional policy-makers would play a prominent role in the definition of the S3 strategy, whereas in the former it is the stakeholders who delineate the strategy for later adoption by the regional authorities. According to Iacobucci (2014), the bottom-up approach is likely to be biased towards the interests of the involved stakeholders, leading the regions to fail in elaborating an overall regional strategy. McCann and Ortega-Argiles (2015) take a moderate position, arguing that S3 should be approached as a 'partnership-based policy process of discovery and learning on the part of both policy-makers and entrepreneurs' (McCann and Ortega-Argiles, 2015, p. 1300). This perspective is currently the prevalent one (Rodriguez-Pose \& Wilkie, 2015; Boschma \& Gianelle, 2014; Foray, 2013).

This view is similar to that of Rodrik (2004), who sees the private sector as responsible for identifying new activities, while the role of the government (policy-makers) is to evaluate the potential of the proposed priorities, and then provide the tools for the most capable actors to foster the development of such priority areas. The policy-making authorities may intervene, as long as that does not undermine the market logic underlying the EDP (Entrepreneurial Discovery Process), according to which the entrepreneurs (broadly understood), through trial and error, identify and define priority areas to be developed in the context of the S3 policy. The prominence accorded to stakeholders in this policy framework helps to achieve a decentralized process of prioritization of activities. The adoption of such framework avoids the older topdown policy approaches that deal with prioritization through centralized and bureaucratic procedures.

\subsection{S3 as a process of related diversification}

Foray (2013) holds that priorities should be defined at an intermediate level of aggregation, somewhere 'between sectors and very micro-activities' (Foray, 2013, p. 59). He also indicates that priority areas should fulfil the principles of inclusiveness (various types of stakeholders should be included), novelty (new sorts of activities should be explored) and relevance (priorities should be pertinent to the regional economy and able to induce structural changes). Thus, emerging new activities should be supported only in the areas that are relevant for those sectors already present in a given territory. 
In other words, S3 fosters existing activities in a given region through the emergence of R\&D and innovation in new domains that complement existing ones, at least to some extent. This in turn promotes the structural evolution of the targeted economies, through an 'accumulative process that links the present and future strengths of a regional economy in a particular domain of activity and knowledge' (Foray, 2013, p. 63). This process will normally have an inherent logic of related diversification, which can take three forms: transition, modernization or diversification in the strict sense (see examples in Appendix A). Concerning transition and diversification (in the strict sense), if resources are scarce, finite and limited, new activities may replace existing ones (totally or partially), so it may be assumed that there will be competition between the emerging activities and the new ones. With modernization, however, the emerging and existing activities are more adequately characterized by 'complementarity'.

In the context of S3 policy, the term 'specialization' should not be misinterpreted as indicating that such policy targets the specialization of the overall economic structure of a given region. Rather, the underlying idea is to promote the emergence of new areas of activity that build on and complement those already existing, thereby fostering a process of related diversification. In this sense, as Foray (2013) puts it, S3 is 'not about generating technological uniformity and mono-culture or prioritizing sectors or eliminating areas of activities' (Foray, 2013, p. 65). On the one hand, if the priorities are complementary to other activities already present in the region, supporting the former will generally give renewed vigour to the latter, so existing and new activities are not necessarily mutually exclusive. On the other hand, this policy is conceived as being dynamic, so that activities defined as priorities at any given point will not be supported forever, as other priorities are discovered and adopted.

In this sense, technological/industrial relatedness can be seen as a guideline that may be followed by regions as part of their process of S3 (Boschma \& Gianelle, 2014). Beyond the fact that relatedness follows the spirit of S3, it appears to have other advantages as well. Relatedness can enhance spillover effects and knowledge transfer, thereby fostering innovation and economic growth at the regional level (see Boschma \& Frenken, 2011, for a review). Moreover, related industrial variety is assumed to have a positive effect on the survival rate of companies (Boschma \& Wenting, 2007; Klepper, 2007), and a positive/negative impact on the probability of their entering/exiting the market (Neffke \& Svensson Henning, 2008). That should not be

\footnotetext{
${ }^{1}$ According to Foray (2013), structural transformation can also be unleashed by a process of radical innovation. However, such cases are not dealt with here.
} 
taken to mean that unrelated activities are not viable in a given territory: merely that relatedness can provide an appropriate framework for approaching the topic of S3.

\subsection{S3, the need of quantitative tools, and related diversification as an adequate framework}

The importance of implementing methodologies to allow the construction of indicators applied to $\mathrm{S} 3$ is recurrently mentioned in the literature (David, Foray \& Hall, 2009; Barca \& McCann, 2011). Moreover, it has been highlighted that empirical studies related to regional S3 are rare, with few attempts as measurement (Iacobucci, 2014; Caragliu \& Del Bo, 2013). With that in mind, Caragliu \& Del Bo (2013) proposed and estimated a new indicator of S3 based on comparative advantages. However, such indicator of S3 is estimated at a low level of desegregation (only for 15 NACE 2-digit industries), attributing little or no importance to the emergence of new activities or the extent to which they are related to the existing regional structure. What is needed is a framework of analysis, as well as (quantitative) indicators more in line with the principles underlying this policy concept (see, for instance, Foray, 2013).

Several scholars have proposed associating S3 with a process of related diversification (Foray, 2013; McCann \& Ortega-Argilés, 2015; Balland et al., 2018). As noted by Boschma \& Gianelle (2014), 'the concept of relatedness provides a tool to identify regional (unused) potentials and a framework to target and select promising activities' (i.e. priority areas) (Boschma \& Gianelle, 2014, p. 9). Beyond the fact that the related diversification approach is one of the main ideas underlying the S3 policy concept, this approach, as highlighted by Boschma \& Gianelle (2014), is well-suited to match the main principles enshrined in the S3 literature, instead of conflicting with most of them. The questionable aspect here concerns the EDP, as the related diversification approaches risk being seen as dealing with prioritization from a centralized perspective. As such, relatedness techniques can be criticized for the absence of entrepreneur intervention in the scope of the vertical prioritization process.

However, Boschma \& Gianelle (2014) indicate that these different approaches are not incompatible, and propose a way to reconcile both perspectives. The logic underlying the S3 policy is not inverted unless policy-maker intervention in the process replaces the role that private partners are expected to play: to make the final decision as to the set of areas and activities with greatest potential to benefit from support in terms of R\&D and innovation. In this sense, what is suggested is the adoption of a sequential approach, whereby, by means of relatedness techniques, a loose set of areas of activity with higher potential to be supported is 
identified. Then, taking these areas as the point of departure, the EDP can be conducted as usual, with the entrepreneurs establishing a vertical prioritization among these pre-selected activities. (Boschma \& Gianelle, 2014).

It is under this general framework of analysis that the following sections in this paper should be interpreted. Employing the ideas of S3, relatedness, and priority areas defined according to their degree of relatedness, this article seeks to propose new indicators to approach the topic of S3. Compared to the existing literature, this is the main novelty of this article. It uses the ideas conceptually discussed by Boschma \& Gianelle (2014) and the framework of analysis proposed by Balland et al. (2018) about the association of S3 with related diversification, and implements new indicators of variety and diversification to evaluate to what extent such processes, in European regions, are in line with the principle of relatedness. Although the development of relatedness and variety indicators is not new in the literature, the indicators proposed here have never been used before. They were conceived specifically to be as much as possible in line with the principles of S3: development of specializations in those domains that are the most promising (i.e. highest relatedness density) in a given region.

\section{Data}

This study uses the OECD REGPAT database, which has information on patent applications to the EPO (European Patent Office) as well as the PCT (Patent Co-operation Treaty). To each single patent application, one (or more) technological fields is/are attributed, according to the IPC (International Patent Classification). In this database most patent applications are regionalized, and each patent application (or a share of it) is attributed to each NUTS3/TL3 (or equivalent territorial unit). This enables the use of fractional accounting in assessing the total number of patent applications attributable to a given region.

For each patent application, the dataset includes information on application year: one variable stating the year of actual application to the patent office in question, and another variable identified as 'priority year', defined as the year in which the patent was first filed. Since the aim here is to measure regional technological achievements, the latter concept will be employed, being closer to when the invention underlying a given patent was actually made. This differentiation is relevant because patent application processes involve administrative and bureaucratic procedures, often resulting in time-lags between when the invention was made and 
when the application is formally registered at the patent office (Maraut, Dernis, Webb, Spiezia \& Guellec, 2008). ${ }^{2}$

Patent applications concerning the EU28 plus EFTA countries (Iceland, Lichtenstein, Norway and Switzerland) were selected. For this group of countries, patent applications were distributed across 44 years, from 1964 to 2015. Overall, for the whole period for these countries, there were 1722152 patent application (see Appendix B). However, in some years there were very few patent applications recorded, which might indicate incomplete data. Therefore, such observations were excluded from the analysis: in practice, the period 1964-1979, as well as observations available for 2014 and $2015 .^{3}$ Thus, this article uses data from all years within the period 1980-2013. This assures a large temporal coverage, and guarantees that the results are less vulnerable to temporary trends that may affect specific regions during given periods.

For each one of the selected years, and for each region available in the dataset, the number of patent applications pertaining to a given IPC class/subclass is computed. Therefore, for each year and region, this yields the total number of existing patents by IPC class/subclass. As shown in Appendix C, counting the total yearly number of patent applications by IPC class, yields results quite different from the total number of patents. In terms of regional territorial units, although data are available at the NUTS3/TL3 level, it was decided to develop the analysis in terms of NUTS2/TL2, because regional data (from other sources) at NUTS3/TL3 level are generally limited. Moreover, NUTS 2 are the units of analysis that most countries consider to design and implement their S3 strategies. Anyway, the choice of other units of analysis, at either higher or lower level of aggregation than NUTS2, may lead to different results and conclusions than those discussed here (see section 6 for more details).

The use of patent data restricts the scope of this article to the analysis of the technological dimension of S3. The choice of such perspective was mainly driven by data availability. As it is well known, patent data assures a temporal and spatial coverage that is unique (OECD, 2009). Moreover, the fact that patents can be highly disaggregated by different technological categories makes such data particularly suitable for studying processes of regional diversification. Nevertheless, the use of patent data as a measure of inventive and technological activity is not exempt of criticisms, as it presents several limitations. For instance, the

\footnotetext{
${ }^{2}$ For further details see Maraut et al. (2008)

${ }^{3}$ As seen in Appendix B, from 2013 onwards there is clearly a break in the series, which is why 2014 and 2015 were excluded from the analysis.
} 
propensity to patent differs substantially across industries (Arundel \& Kabla, 1998) and firms, being more difficult to small and new firms to cover patenting costs (OECD, 2009).

\section{Methodology}

\subsection{Step 1 - Revealed Comparative Advantage}

The first step is to follow the procedures set out by Hidalgo, Klinger, Barabási and Hausmann (2007) and Montresor and Quatraro (2017), among others, to determine the DoP (degree of proximity) among all technological fields attributed to the patent applications in the dataset. First, for each year and region, the RCA (Revealed Comparative Advantage) is computed for each individual technological field (IPC class or subclass) with at least part of a patent application attributed to it. The RCA is computed according to the following formula:

$\mathrm{RCA}_{\mathrm{izt}}=\frac{\text { PATizt }}{\sum_{z=1}^{n} \text { PATizt }} / \frac{\sum_{i=1}^{m} \text { PATizt }}{\sum_{i=1}^{m} \sum_{z=1}^{n} \text { PATizt }}$

where $\mathrm{RCA}_{\mathrm{izt}}$ represents the Revealed Comparative Advantage of region $\mathrm{i}$, in technology $\mathrm{z}$, at year $\mathrm{t}, \mathrm{PAT}_{\mathrm{izt}}$ is the number of patent applications attributed to technological field $\mathrm{z}$ in a given region $\mathrm{i}$ and year $\mathrm{t}$, while $\mathrm{n}$ and $\mathrm{m}$ refer to the total number of technologies and regions, respectively. This indicator, for a given year $t$ and region $\mathrm{i}$, compares the regional share of patents regarding a given technology $\mathrm{z}$, to the share of patents for the same technology as computed for all other regions at time $\mathrm{t}$ - thus showing whether a given region, at a given time point, is relatively more or less specialized in a given technology than the rest of the world (all other regions together). If for a given year, region, and technology the indicator has a value greater than one, that means that region $\mathrm{i}$, in year $\mathrm{t}$, has a specialization in technology $\mathrm{z}$.

\subsection{Step 2 - Degree of proximity and relatedness among technological fields}

Then, for each region and year, all combinations of two technological fields are established for which a given region, in a given year, has at least a share of a patent application. Having this, the DoP between technologies composing a given pair is computed following the formula below, where $\mathrm{a}$ and $\mathrm{b}$ represent two different technological fields:

$\Omega_{\mathrm{ab}}=\min \left\{\mathrm{P}\left(\mathrm{RCA}_{\mathrm{a}}>1 \mid \mathrm{RCA}_{\mathrm{b}}>1\right), \mathrm{P}\left(\mathrm{RCA}_{\mathrm{b}}>1 \mid \mathrm{RCA}_{\mathrm{a}}>1\right)\right\}$, 
where $\mathrm{P}\left(\mathrm{RCA}_{\mathrm{a}}>1 \mid \mathrm{RCA}_{\mathrm{b}}>1\right)=\frac{\mathrm{P}\left(\mathrm{RCA}_{\mathrm{a}}>1 \cap \mathrm{RCA}_{\mathrm{b}}>1\right)}{\mathrm{P}\left(\mathrm{RCA}_{\mathrm{b}}>1\right)}$

In (2) $\Omega_{a b}$ indicates the DoP between technologies a and $b$, while the expression $\mathrm{P}\left(\mathrm{RCA}_{\mathrm{a}}>1\right.$ | $\mathrm{RCA}_{\mathrm{b}}>1$ ) represents the conditional probability of there being, in the sample, cases where technology a has a RCA $>1$ given that for technology $\mathrm{b}$ RCA $>1$. As regards computing $\Omega_{\mathrm{ab}}$ and its underlying probabilities, in the sample one observation is a pair composed of a region and a year. Overall, the sample contains more than 8000 pairs of years (1980-2013) and regions. The DoP between two technological fields is computed on the basis of the frequency of finding the co-occurrence of a specialization $(\mathrm{RCA}>1)$ in these fields, in the sample of pairs regions-years being analysed.

Although, there are specific techniques to determine technological relatedness, using, for instance, patent citations (Leten et al., 2007) or the co-occurrence of different technologies in the same patent (Breschi et al., 2003; Quatraro, 2010), the article adopts a more general approach based on the concept of RCA (Montresor and Quatraro, 2017). Such approach is followed because RCA methodology can be easily replicated to other sorts of datasets (traded products, employment by NACE 2 sectors, etc.). This feature can allow all that are interested in the topic to extend this analysis (upon data availability), in the future, to other categories of relatedness (beyond technological one). Such exercise would permit exploring other dimensions of S3, and therefore complement the proposed indicators.

'The fact that two technological fields are frequently observed as distinctive advantages across regions may imply that they rely on similar or complementary capabilities and competences' (Montresor and Quatraro, 2017, p.393). However, the criticisms underlying the use of RCA, when mobilized for the measurement of the degree of proximity between technologies, are well known. For instance, Rigby (2015) points out that 'The colocation of patents from different technology classes might be a reasonable proxy for technological relatedness, but might also be a proxy for unspecified economic relationships that display positive spatial autocorrelation' (Rigby, 2015, p. 1926).

In this this article, technologies are proxied by IPC technological classes. This is the most common classification system when EPO patent applications are used. The adoption of 122 IPC classes (technological domains aggregated at 3-digit level) intends to match the level of analysis that is relevant to S3: mid-grained granularity - an intermediate level of aggregation (Foray, 
2013). Although in the technological diversification literature higher levels of technological disaggregation may be adopted (Boschma et al. 2015; Rigby, 2015), the choice of IPC classes is according to Balland et al. (2018), who also propose a technological diversification framework for investigating S3 processes in European regions.

\subsection{Step 3 - Ranking different technologies according to their average proximity to technological capabilities in different regions}

To compute the indicators (see next steps) it is necessary to determine the average DoP between each technology (present or not in a given region) and all other technologies in which a given region has a specialization (RCA $>1)$. That makes it possible to identify, for each region, to what extent the logic of S3 is already embedded there. The ascription of regional embeddedness potential to a given technological area is based on the the average DoP between that area and the technological fields where there are technological specializations for a given region and year. To compute for each one of the technologies their average degree of proximity with the technological specializations found in that region, the following formula is employed:

$\operatorname{AvgDoP}$ zit $=\frac{f_{z i t}}{F_{i t}}$

where $\mathrm{f}_{\mathrm{zit}}=\sum_{v \neq z} \Omega_{\mathrm{vz}}$

In equation (4), $\operatorname{AvgDoP}{ }_{z i t}$ is the average degree of proximity of a given technological field $\mathrm{z}$ with all other technological specializations $\mathrm{v}$ that are present in a given region $\mathrm{i}$ and year $\mathrm{t} ; \mathrm{F}_{\mathrm{it}}$ is the total number of technological fields $v$ for which there is technological specialization in region $i$ at year $t$; and finally, $f_{\text {zit }}$ is the sum of the DoP between technological specializations $v$ existing in region $\mathrm{i}$ at year $\mathrm{t}$ and technological field $\mathrm{z}$. This indicator shows the extent to which each technological field $\mathrm{z}$ is related to other technological specializations $\mathrm{v}$ present within a given region. The index ranges between 0 and 1, where values closer to 0 represent the case in which, for a given year and region, a given technology $\mathrm{z}$ is weakly related to the set of technological specializations v present in that region for that year. Conversely, values closer to 1 indicate the contrary.

Having computed the average degree of proximity for all existing technological fields, in all regions and years integrating the dataset, the next step is, using this indicator, to rank technologies. Here it is assumed that the technological field $\mathrm{z}$ with the lowest AvgDoP is ranked 
1. This means that for a given region and year, the rank of a technology $\mathrm{z}$ is 1 plus the number of technologies whose AvgDoP is lower than z.

$\operatorname{Rank}_{\mathrm{zit}}=1+\sum_{s \neq z} \mathrm{~S}_{\text {sit }}$

where $S_{\text {sit }}=1$ if $\operatorname{AvgDoP}_{\text {sit }}<\operatorname{AvgDoP}_{\text {zit }}$

$\mathrm{S}_{\text {sit }}=0$ if $\mathrm{AvgDoP}_{\text {sit }}>\mathrm{AvgDoP}_{\text {zit }}$

where Rank $\mathrm{z}_{\mathrm{zit}}$ represents the ascending rank of technology $\mathrm{z}$ in region $\mathrm{i}$ and year $\mathrm{t}$ in terms of average degree of proximity, while $S_{\text {sit }}$ should be interpreted as a dummy variable that takes the value 1 if a technology $s$ in a given region $i$ and year $t$ has a AvgDoP lower than the AvgDoP of technological field $\mathrm{z}$.

\subsection{Step 4 - The static indicator: Monitoring initial conditions}

To what extent, then, is the logic of S3 already embedded in the regions? To answer this question, this indicator is intended to grasp, at a given point in time, to what extent the situation of European regions in terms of technological variety is in line with the principles underlying S3 (i.e. related diversification). For instance, this may constitute an important tool to understand where European regions stand when S3 policy starts its implementation. While in some regions major efforts may be required, in others this logic may have a long tradition, which is likely to ease the implementation of S3 policy. The indicator is computed as follows:

Static $_{i t}=\sum_{z} \frac{\text { Rank }_{\mathrm{zit}} \text { Spec }_{z i t}}{\text { MaxRank }}$

such that:

MaxRank $_{\mathrm{it}}=\max$ Rank $_{\mathrm{zit}}$

$\operatorname{Spec}_{\mathrm{zit}}=1$ if $\mathrm{RCA}_{\mathrm{zit}}>1$

$\operatorname{Spec}_{\mathrm{zit}}=0$ if $\mathrm{RCA}_{\mathrm{zit}} \leq 1$

where Static ${ }_{i t}$ represents the degree of variety of region $i$ in year $t$ and to what extent such variety is in line with the principle of technological relatedness; MaxRank $\mathrm{it}_{\mathrm{t}}$ should be interpreted as the 
highest rank verified in region $\mathrm{i}$ and year $\mathrm{t}$; and $\mathrm{Spec}_{\mathrm{zit}}$ is a dummy that takes the value 1 if in year $\mathrm{t}$, region $\mathrm{i}$ has a specialization in technology $\mathrm{z}$. This indicator shows to what extent a given region has already acquired specializations $(\mathrm{RCA}>1)$, attributing higher weight to those whose rank is higher and therefore have stronger potential for regional embeddedness. Each component of the sum belongs to ]0, 1], such that regional technological specializations that reveal the lowest proximity to the existing regional technological capabilities are very close to zero. Reversely, if the region is specialized in technologies that present the highest rank, they contribute to the sum as one. At bottom line, specializations that are more distant to the existing regional technological capabilities provide a modest contribution to the indicator. Oppositely, specializations that are closer to the existing regional technological endowments provide the most relevant input to (8). ${ }^{4}$

Finally, as the upper and lower limits of (8) vary from period to period, and as one of the objectives of this article is to carry out comparisons across different periods, in each year $\mathrm{t}(8)$ is rescaled to go from 0 to 1 . The conversion is implemented as follows:

Rescaled Static it $=\frac{\text { Static }_{i t}-\text { MinStatic }_{i t}}{\text { MaxStatic }}$

\subsection{Step 5 - The dynamic indicator: Monitoring evolution}

The second indicator is a dynamic monitoring tool, since it is designed for measuring to what extent European regions, during a given time period, acquire new specializations and to what extent such areas are closely related to previous regional specializations. The evolution of a given region is here defined in terms of its acquisition of new specializations during a five-year timespan (Balland et al, 2018; Cortinovis et al., 2017, Xiao et al., 2016). As previously, this indicator also attributes a higher weight to new specializations that are closer to pre-existing technological specialization structure of the region:

Dynamic $_{\mathrm{it}, \mathrm{t}+5}=\sum_{z} \frac{\text { Rank }_{\mathrm{zit}} \text { NewSpec }_{z i t+5}}{\text { MaxRank }_{i t}}$

such that:

\footnotetext{
${ }^{4}$ As a robustness check, the indicator has been recomputed, but now assuming Fit as the total number of technological fields for which there is at least a share of a patent attributed to the region $\mathrm{i}$ at year $\mathrm{t}$, while fzit should be now interpreted as the sum of the DoP between technological fields existing in region $i$ at year $t$ and technological field $\mathrm{z}$. As the two version of the indicator do not yield substantially different results, the paper uses only the first version of the index.
} 
$\mathrm{NewSpec}_{\mathrm{zit}+5}=1$ if $\mathrm{RCA}_{\mathrm{zit}+5}>1 \wedge \mathrm{RCA}_{\mathrm{zit}} \leq 1$

NewSpec $\operatorname{zit}_{+5}=0$ if $\left(\mathrm{RCA}_{\mathrm{izt}}>1 \wedge \mathrm{RCA}_{\mathrm{izt}+5}>1\right) \vee \mathrm{RCA}_{\mathrm{izt}+5} \leq 1$

and $\mathrm{z} \in \mathrm{NonSpec}_{\mathrm{it}}$

where NonSpec $\mathrm{it}_{\mathrm{it}}$ is the set of technologies that in a given year and region satisfy the following condition:

$\mathrm{RCA}_{\mathrm{zit}} \leq 1$

where Dynamic $c_{i t, t+5}$ is an index measuring the evolution of region $i$, between year $t$ and $t+5$, in terms of the acquisition of new specializations, and NewSpec $\mathrm{zit}_{+5}$ is a dummy that takes the value 1 if, as of year $\mathrm{t}$, the region i did not have a specialization in $\mathrm{z}$, but acquired it five years later. MaxRank $\mathrm{it}_{\mathrm{it}}$ and $\mathrm{Rank}_{\mathrm{zit}}$ are defined as previously, with the difference that now only technologies in which regions are not specialized in are ranked (see conditions (14) and (15)). As previously, the index is rescaled to range between 0 and 1.5

\section{Results}

The empirical analysis starts by observing the static indicator (8) that measures the degree of technological variety exhibited by a given region, and the extent to which such variety includes technologies that are the most related to existing regional technological capabilities, for each year. Table 1 presents the descriptive statistics for this indicator for those years for which it is computed. The number of observations per year increases over time - the sample includes 225 regions in 1990, 258 in 2000, and 275 in 2013 - because some regions have reported patent data only for recent years. Concerning the results obtained for the rescaled index (11), the average value ranges between 0.39 (in 1990) and 0.43 (in 2013). On the one hand, this means that, on average, the analysed regions are below the centre of the scale (i.e. 0.5). On the other hand, their average performance has slightly improved over time. In 2013, the maximum value observed for the rescaled static indicator was found in the region of Veneto (northeastern Italy).

\footnotetext{
${ }^{5}$ Two versions of this indicator are computed: one, referred to as 'standard', where NonSpec is simply considered as the set of fields without a specialization at time $\mathrm{t}(\mathrm{RCA} \leq 1)$, and another, 'restrictive', where NonSpec includes only technologies with RCA $<0.5$ at time t. The paper uses only the standard version of the index, whereas the two versions (standard and restrictive) do not yield substantially different results.
} 
In that year, the region with the lowest score was Stredne Slovensko (Slovakia). This means that in 2013, this region had few specializations in those technologies in which it had the highest potential for regional embeddedness. The maximum value of related variety in absolute terms (38.14) was recorded in 2000, for Arnsberg (Germany). In 2000, the region with the lowest scores also registered 0 for the indicator in question: Severozapaden (Bulgaria). Finally, in 1990, the highest value was verified again in Arnsberg (Germany). The lowest level corresponds to Cantabria.

\section{< Table 1 about here >}

Observing the left-hand side of figure 1, there are two main conclusions to be drawn. First, between 1990 and 2013, most of the regions show a positive evolution in the static index, indicating improvements over time in the acquisition of specializations in technologies with the highest regional embeddedness potential (despite a few exceptions). This is especially visible for some less developed regions. For instance, in 2013, figure 1 shows that some peripheral regions present high scores. Second, almost all regions that occupy leading positions are located at the core of the European continent or in the north, whereas lower scores are found in regions in eastern and southern Europe (mainly Portugal, Southern Italy and Greece). This fact suggests that, probably, data are not randomly distributed across space. This hypothesis is confirmed by

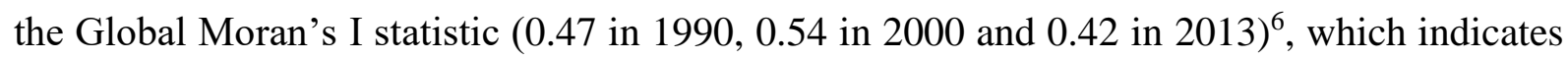
that, globally, the value of the static indicator in a given region is more similar to its immediate neighbours than it would be the case randomly (see right-hand side of figure 1). As the righthand side of figure 1 shows, this global statistic is driven by the Local Moran's I statics of those regions in the $1^{\text {st }}$ quadrant (regions in leading positions surrounded by leading neighbours) and $3^{\text {rd }}$ quadrant (regions in bottom positions surrounded by low performing neighbours), while remaining observations contradict this trend.

\section{$<$ Figure 1 about here >}

Appendix D shows that Austria has the highest median value for the static indicator in 2013 (0.62). The lowest median values in 2013 are for Bulgaria, Greece and Romania. In 2000, the highest median value was recorded in Lichtenstein, followed by Austria, Germany, Sweden, Finland, Denmark, Luxembourg and France, all with a median above 0.5. Among the countries

\footnotetext{
${ }^{6}$ Moran's I statistics are computed based on regional (queen) contiguity. Thus, non-neighbors (regions that do not share the same border) are assigned 0 in the spatial weights matrix. For the sake of simplicity, Islands are excluded from the computation of Moran's I statistics.
} 
with lower median values, are the Bulgaria, Czech Republic, Estonia, Greece, Hungary, Lithuania, Malta, Poland, Portugal, Romania and Slovakia, all with median scores lower than 0.2. Also in 1990, the countries with the highest figures for median value of the static indicator are Switzerland (0.71), Lichtenstein (0.68), Sweden (0.62), Germany (0.57), Finland (0.56), and France (0.55). Bulgaria, Croatia, Greece, Hungary, Iceland, Poland, Portugal, Romania, and Slovakia were the lowest. Appendix E corroborates this impression of a dichotomy between northern / central European regions on the one hand, and southern and eastern European regions on the other. In 2013, most countries where less than half of the regions exhibited a score of the static indicator below the median were mainly in southern and eastern Europe, whereas those where more than half of the regions were above-median score were mainly northern and central European countries. There are some exceptions, however.

To what extent, then, is there a correlation between the static indicator, and some regional macroeconomic variables - GDP per capita in particular? Analogously, is there a correlation between the proposed index and other regional indexes (Regional Competitiveness Index, Regional Innovation Index, and the Regional Quality of Institutions Index)? ${ }^{7}$ Moreover, given the way the indicator (8) was constructed (using data on patents), it is also important assess the correlation between the index and the number of patents within each region (the absolute numbers and per capita values). A high degree of positive correlation between patents and the proposed index might mean that the indicator could be biased, as it attributes (by construction) higher scores to regions with higher absolute/relative numbers of patents. However, as shown in Table 2, this is not the case: the existing correlation between the proposed indicator and patents (total number and per capita values by region), although positive, is very low. Concerning GDP per capita, as expected, there is a moderate and positive correlation between this variable and the indicator. Although stronger, the correlation between the proposed indicator and each of regional indexes mentioned above is also positive and moderate. In other words, the fact that northern and core central European regions perform better in the achievement of technological specializations with higher regional embeddedness potential, is not simply explained by the fact that these regions have typically a higher level of economic and technological development. It seems to be more related to their competitive, innovative and quality of institutions performance. Anyway, again, these elements do not explain all. Probably,

\footnotetext{
${ }^{7}$ Data on these indexes are collected from Annoni \& Dijkstra (2013)
} 
patterns of specialization in top priority areas are also related to policy strategies and choices made by the regional and national authorities.

\section{$<$ Table 2 about here $>$}

Table 3 presents descriptive statistics on the computation of indicator (12), which reflects to what extent regions, between year 2008 and 2013, acquired new specializations, and the extent to which such new specializations are those most related to the existing regional technological capabilities. ${ }^{8}$ The indicator was computed for 269 regions and its average is equivalent to 0.44 . This means that, on average, in 2013, the performance of the analysed regions is slightly below the centre of the scale. The highest score goes to Autonomous Province of Trento (northern Italy); the regions with the lowest scores are Sud-Est (in Romania), Notio Aigaio (Greece), Algarve and Alentejo (both in Portugal), and Corse (France).

\section{$<$ Table 3 about here $>$}

The geographical distribution of regions' scores on this indicator (see figure 2) shows that regions with the highest scores are somewhat more widely spread across the continent than in the static indicator (see figure 1). High scores for the core of Europe are less predominant, compared to the static indicator; and some southern (e.g. Spain) and eastern European regions exhibit very high scores, although some central European regions have quite low scores. This means that some peripheral European regions have been evolving towards acquiring new technological specializations in domains that are closely related to those that existed previously in the regions. To some extent, this trend confirms that S3 may be a feasible strategy for noncore peripheral areas, mainly in Southern and Eastern Europe, despite the huge challenges these regions still face (McCann \& Ortega-Argiles, 2016). Although the results discussed here cannot be attributed to S3, they confirm that even some of the regions located in geographical areas that typically exhibit lower scores in terms of related diversification, are able to engage in the spirit of S3. This reinforces the idea that S3 applies to every region, regardless its level of economic development.

$<$ Figure 2 about here >

\footnotetext{
${ }^{8}$ As a robustness check, the indicator was also computed for the periods 2009-2013 and 2010-2013. However, the change of the time window does not yield substantially different results.
} 
One potential limitation of this index is the fact that at time $t$, the number of technological specializations differ from region to region. This implies that the number of technologies in which each region is potentially able to create new specializations, between $t$ and $t+5$, also differs substantially. As the indicator proposed in (12) is additive, it is possible to think that it might be biased towards regions with more opportunities of new specializations, overestimating their diversification performance. To investigate this, Table 4 shows the correlation between the indicator and the number of technologies in which each region is potentially able to create new specializations, between $\mathrm{t}$ and $\mathrm{t}+5$. However, the correlation between both variables is negative (see Table 4). This means that there is a negative association between more unexplored specializations, and the regional performance in terms of the dynamic indicator.

$<$ Table 4 about here $>$

Another potential limitation is that as in (12) MaxRank differs from one region to another, it would be possible to argue that regions where MaxRank is higher, the contribution of each element of the sum (each technology in which regions acquire new specializations) might be of lower magnitude, justifying therefore the negative correlation discussed above. However, the average strength of each technology (see table 5) is almost the same in all regions, regardless their number of unexplored specializations. Briefly, this means that what matters is in how many and what technologies regions create new specializations, and not the number of technologies that the region has available to do so.

\section{$<$ Table 5 about here $>$}

Finally, applying the static indicator for 2000 and 2013, a cluster analysis exercise ${ }^{9}$ is performed. For each of these years, the sample of regions is split into two non-overlapping groups corresponding to those with the highest (leaders) and lowest (followers) scores. Depending on the category attributed to each region in both periods, territories are then categorized as Technological S3 persistent leaders (leaders in both years), Technological S3 recent leaders (followers in 2000, leaders in 2013), Technological S3 persistent followers (followers in both years), and Technological S3 recent followers (leaders in 2000, followers in 2013). Further, the static index is used in its rescaled version (see equation 11). The cluster analysis yields 0.43 as the threshold for the static indicator in 2000. Regions with a score below this threshold are seen

\footnotetext{
${ }^{9} \mathrm{k}$ means
} 
as Technological S3 followers; those with a score above are seen as Technological S3 leaders. For 2013 the threshold is fixed at 0.38 .

Figure 3 shows the representation of the regions, and their classifications, according to the established thresholds resulting from the cluster analysis described above. Appendix F presents in detail the values attributed to the regions, and their standing in terms of the four categories. The upper right-hand portion of the graph (persistent leaders) shows the dominance of German regions, along with some Italian, Finnish and Austrian territories, among others. In the bottom left-hand portion (persistent followers) are several regions belonging to southern and eastern European countries, notably Bulgaria, the Czech Republic, Greece, Hungary, Poland, Portugal, Romania, and Slovakia (see Appendix G). However, in the 'persistent followers' category there are also some Austrian, German, Finnish, French, British, Swedish and Dutch regions. Thus, regional heterogeneity in terms of the ability of the regions to diversify into those technologies with higher regional embeddedness potential is found not only among regions of different countries, but within countries as well.

As to recent leaders, Figure 3 highlights, for instance, Galicia (ES11) as showing a noteworthy development between 2000 and 2013. This region evolved from a score equivalent to 0.18 in 2000 , to more than 0.61 in 2013. Interestingly, the top left-hand portion of the chart (recent followers) has few regions, which would indicate that regions once considered to be Technological S3 leaders rarely worsen their standing substantially later on - as with Upper Palatinate (DE23) and Continental Croatia (HR04).

$<$ Figure 3 about here >

\section{Discussion of the indicators and the delineation of the data: time, space and technologies}

This paper provides indicators specifically applied to S3. The gradual construction of these indicators (step by step) allows the easy replication of the proposed indexes, using other datasets, units of analysis (other than NUTS 2) and time-periods. Moreover, this can be done even for other purposes, beyond S3. Although the results of the indicators are always contingent on the data and methods adopted, the article has proposed several robustness checks to confirm that its main conclusions do not change substantially when there are variations in few of the adopted methodological decisions. Nevertheless, there are aspects related to the delineation of the data that require a more careful discussion, especially in case the indicators are used in other contexts. 
The first caveat is the time-period selected to compute regional technological specializations. Once a new patent is invented, it can be exploited for several years. Thus, it might make sense to think that the computation of technological specializations of a given region, in a given year, should not consider, exclusively, patent applications of that year. Thus, an alternative approach would have been computing regional technological specializations based on the overall stock of patent applications that exist in a given region. However, such method has few drawbacks. Computing regional technological specializations based on current and past patent applications would imply considering patent applications that are too distant in time. The risk is that the technologies that such patents represent are both obsolete and no longer relevant for the region. To avoid including irrelevant patent applications in the computation of the regional technological specializations, it would be necessary defining a time threshold. Such threshold would determine which previous years' patent applications would be relevant, and which ones would be irrelevant. However, this decision would always be random.

Moreover, computing technological specializations of the regions based on a single year patent applications' data, only means that a new trend is emerging and the region is diversifying following such trend, which is exactly what this paper seeks to investigate. Therefore, the fact that a given region is not considered specialized in a given technology based on yearly data (and it might be considered specialized when several years' patent applications are considered), simply means this technology does not belong to the new wave of technological specializations that is emerging, while others belong. This approach captures better the evolutionary nature of S3 processes, than an alternative approach where too distant and obsolete technologies are also considered. Moreover, as such approach allows a contemporaneous assessment of the evolutionary path regions are following, it will be more useful for policy makers as a monitoring tool.

The second important caveat is the delineation of the data across space (i.e. the territorial units adopted for the analysis). The paper selects NUTS 2 as units of analysis because, beyond the fact they are the functional regions that most countries consider to design and implement their S3 strategies, Eurostat also regards NUTS2 as the relevant territorial units for the application of regional policies. However, it can be the case that that these are not functional regions for more specific diagnoses, such as to analyze how different industries or technologies are clustered across the space. It can be the case that different regions when analyzed together are specialized in given technologies, while individually they are not. Reversely, sub regions within each NUTS2 may also be considered specialized in specific technologies, while the overall 
NUTS2 are not. These aspects may be particularly relevant if the proposed indicators are mobilized to perform more micro-level analyses, such as investigating the dispersion of specific sectors or technologies across the space.

If so, one important issue may be to understand what the relevant spatial units are, to study the clustering of similar or related technologies. This may differ from country to country, and even within countries, depending on the technologies, industries or sectors at stake. The aggregation of the data into specific spatial units, according to the objective of the research, may have implications, for instance, in the analysis of distance decay effects. The intensity of spatial interactions between territories (and between their technological sectors) will depend on how regions are operationalized. This will influence both the distance assumed to exist between territories, as well as their intensity in different technologies and activities. For all these reasons, delineation of the data across the space requires caution, as it should match the specific objectives of the research.

The third and last caveat concerns technologies, namely their categorization system and the methods adopted to compute technological relatedness. The adoption of technologies according to the IPC categorization system, and their operationalization using three digits, is also contingent on the objective of the research. As discussed above, this choice is mainly driven by the objective this article: provision of indicators applied to S3. However, if the indicators are used for other purposes, it may make sense to operationalize technologies in alternative ways. This would be the case, for instance, if the research were focused on a specific set of technologies (e.g. green technologies, nanotechnologies, ICT related technologies). In such case, it may be necessary an alternative (and more detailed) operationalization of technological categories.

As previously discussed in section 4.2 , the degree of proximity between technologies is the outcome of the co-occurrence in the space of technological specializations. This may be regarded as an ex-post measure of relatedness inspired, for instance, in Hidalgo et al. (2007). This slant contrasts with ex-ante approaches to relatedness, according to which proximity is determined a priori, regardless any empirical pattern demonstrated by the data (e.g. cooccurrence in the space of technological specializations, patent citations, the co-occurrence of different technologies in the same patent, etc.). This ex-ante perspective is adopted in the widely used entropy measures of relatedness. One well know example is Frenken et al. (2007) who, to evaluate the degree of related variety in employment in Dutch regions, measure the variety of 
employment in five digit sectors (of economic activity), within two digits sectors (of economic activity). The implicit assumption is that all sectors that share the same 2 digits are related, as they belong to the same parent group, according to a pre-defined taxonomy.

Following this method, technological relatedness would be based on a pre-existing hierarchical categorization of technologies (for instance, the IPC classification system). However, relatedness would be very dependent on the categorization system adopted. Moreover, such approach would not allow the vertical prioritization of technologies according to their degree of proximity to the existing regional technological structure (see section 4.3). It would only determine whether technologies are related or unrelated. However, it would be impossible a strict prioritization of technological domains according to their potential for embeddedness in the regional technological structure. Oppositely, ex-post approaches seem much more adequate. They allow the computation of a continuous variable that evaluates the degree of proximity between different pairs of technologies, enabling strict prioritization of technologies.

Although this is the approach adopted in this paper, it also implies few limitations. For instance, section 4.3 ranks technologies according to their degree of proximity to the existing regional technological structure. However, the use of the ranks to construct the indicators (see sections 4..4 and 4.5) determines, implicitly, the adoption of an ad-hoc weighting of the different technological domains. As such, another weighting scheme may have resulted in a different outcome than the one obtained. In spite of this limitation, this choice allows prioritization, which is an important aspect to S3. Nevertheless, the use of the proposed indicators to investigate alternative research topics may require adjustments.

\section{Conclusions}

The concept of S3 has been growing in importance, becoming a regional innovation policy concept aimed at fostering $R \& D$ and innovation investments in activities deemed to have greater potential for regional economic development. Operationalization of this concept requires vertical prioritization, which should be done through an EDP, as described earlier.

What has been lacking is an analytical framework for dealing quantitatively with S3, while respecting its main principles. This article has proposed employing the concept of related technological diversity in order to frame this policy concept. Under such framework, two indicators are proposed: one that measures, at a given point in time, to what extent a given region has specializations in those technologies with highest relatedness density, and one that 
evaluates, over time, to what extent regions acquire new specializations in related areas. These indicators are conceived being as much as possible in harmony with the main principles set out in the literature on S3 policy.

Testing these indexes by means of data on patents has indicated that the process of related technological diversity is more developed in regions in the core and the north of the European continent. In contrast, regions in southern and eastern Europe persistently exhibit lower scores. As regards development between 2008 and 2013, the highest and lowest scores are scattered across Europe, but with a concentration of below-average scores in eastern Europe. This aggregation of very high and very low results in certain geographical areas may indicate spillover effects associated with this policy concept. Despite the dichotomy between the northern and central regions, and the southern and eastern regions, the analysis reveals noteworthy dissimilarities across regions within the same country. On the one hand, especially in the most recent years, relatedness is becoming more and more dispersed. There are top performing regions in terms of relatedness that are located in peripheral and economically disadvantaged areas of Europe. On the other hand, within countries heterogeneity may indicate that S3 and its inherent logic of related diversification should be seen as not depending solely on national policies: also region-specific factors need to be taken into consideration. All this supports S3 as a policy potentially adequate for all European regions, including non-core and less developed ones. Nevertheless, the persistence of some low performing regions highlights some deeply rooted problems that policy makers should carefully consider to make S3 a successful policy initiative for every European regions.

Division of the sample into different groups of regions according to their relative degree of technological related variety in 2000 and 2013 indicates that most of the territories examined can be categorized as either technological S3 persistent leaders or technological S3 persistent followers: substantial changes in the relative position of the regions are fairly rare. It is even rarer to find regions that qualify as technological S3 recent followers (regions whose relative position fell substantially between 2000 and 2013). This may indicate that, having engaged in a strong pattern of related technological variety, a region will tend to follow persistently such standard.

Although the idea of S3 should be applicable to any region, the indicators, computed using patent data, can be estimated only for regions and years with patents in more than one technology. Further research should focus on developing more inclusive indicators applied to 
the concept of S3. As highlighted by McCann \& Ortega-Argiles (2016), 'the benefits of RIS3 tend to be multi-dimensional rather than purely technological and research-related, also involving institutional and governance dimensions'(McCann \& Ortega-Argiles, 2016, p.14221423). Anyway, the proposed indexes should be regarded as a complementary tool to others available (see, for instance, the S3 Platform). Another strand for future research concerns the determinants of the ability of regions to follow a S3 pattern. The results indicate that GDP per capita and the institutional framework existing within each specific region should be seriously considered as elements with some explanatory power over the capacity of the regions to diversify into the most related technologies. However, further investigation is needed here.

Finally, this study, based on the technological topography of selected regions, has sought to enable some conclusions on their situation in terms of related diversification. The objective of this exercise has been to explore the technological dimension of the concept of S3, creating indicators able to embed some principles of technology-related diversification that are inherent to the logic S3. Future research should investigate to what extent the regional S3 strategies of different territories are in line with the technology-related diversification logic applied in this study.

\section{Acknowledgements}

I would like to thank Fulvio Castellacci, for guidance, help and advice with this paper. His comments have significantly improved the quality of the manuscript. I would also like to thank Francesco Di Comite for detailed and helpful comments. Further, my thanks go to Dominique Foray, Eric Iversen, Christine Mee Lie, Gianluca Orsatti, two anonymous referees of this journal, the Editor-in-Chief, Paul Elhorst, and a co-Editor of this journal, for comments on earlier versions of the paper. My thanks also to the organizers and participants of the 5th Governance of Complex World Conference on "Innovation, Employment and the Environment" in Valencia (2016), the 2016 ERSA Summer School in Milan, and the 1st SMARTER Conference on Smart Specialisation and Territorial Development in Seville (2016). Responsibility for any remaining errors and shortcomings is mine alone.

\section{References}

Annoni P. \& Dijkstra L. (2013), EU Regional Competitiveness Index - RCI 2013, JRC Scientific and Policy Reports, European Commission 
Arundel , A. \& Kabla, I. (1998), What percentage of innovations are patented? Empirical estimates for European firms" Research policy 27, 127-141

Balland, P.A., Boschma, R., Crespo, J. \& Rigby, D. (2018). Smart specialization policy in the EU: Relatedness, knowledge complexity and regional diversification, Regional Studies, forthcoming

Barca, F. \& McCann, P. (2011), Methodological note: outcome indicators and targets - towards a performance oriented EU cohesion policy, at http://ec.europa.eu/regional_policy/_sources/docgener/evaluation/doc/performance/improve_i nno_resear_en.pdf, accessed 21.05.2016

Boschma, R. (2014), Constructing regional advantage and Smart Specialisation: Comparison of two European policy concepts, Scienze Regionali, Italian Journal of Regional Science, 13(1), $51-68$.

Boschma, R., Balland, P.A. \& Kogler, D.F., (2015). Relatedness and technological change in cities: the rise and fall of technological knowledge in US metropolitan areas from 1981 to 2010, Industrial and Corporate Change, 24, 223-250.

Boschma, R. \& Frenken, K. (2011), Technological relatedness and regional branching, in H. Bathelt, M.P. Feldman \& D.F. Kogler (eds) Beyond Territory: Dynamic Geographies of Knowledge Creation, Diffusion and Innovation. London, Routledge.

Boschma, R. \& Giannelle, C. (2014), Regional branching and Smart Specialization policy, S3 Policy Brief Series No. 06/2014, JRC-IPTS, Seville, May

Boschma, R., Martin, V. \& Minondo, A. (2015), Neighbor regions as the source of new industries, Papers in Evolutionary Economic Geography, 15.08, March.

Boschma, R., Minondo, A. \& Navarro, M. (2012), Related variety and regional growth in Spain, Papers in Regional Science, 91(2), 241-256.

Boschma, R. \& Wenting, R. (2007), The spatial evolution of the British automobile industry, Industrial and Corporate Change, 16(2): 213-238.

Breschi, S., Lissoni, F., \& Malerba, F. (2003), Knowledge-relatedness in firm technological diversification, Research Policy, 32, 69-87 
Camagni, R. \& Capello, R. (2013), Regional innovation patterns and the EU regional policy reform: Toward smart innovation policies, Growth and Change, 44 (2), 355-389.

Caragliu, A. \& Del Bo, C. (2013), Smart specialization strategies and smart cities: an evidencebased assessment of EU policies, Working Paper 2013/17, Dipartimento di Economia, Management e Metodi Quantitativi, Università Degli Studi di Milano

Cortinovis, N., Xiao, J., Boschma, R. \& van Oort, F. (2017). Quality of government and social capital as drivers of regional diversification in Europe, Journal of Economic Geography, $\underline{\text { http://doi.org/10.1093/jeg/lbx001 }}$

David, P., Foray, D. \& Hall, B. (2009), Measuring Smart Specialisation: The concept and the need for indicators, CEMI - the Chair of Economics and Management of Innovation, at http://cemi.epfl.ch/files/content/sites/cemi/files/users/178044/public/Measuring\%20smart\%20 specialisation.doc, accessed 05.05.2016

Essleztbichler, J. (2015), Relatedness, industrial branching and technological cohesion in US metropolitan areas, Regional Studies, 49:5, 752-766.

Foray, D., David, P.A. \& Hall, B.H. (2009), Smart Specialization - the concept, Knowledge Economists Policy Brief 9, European Commission, Brussels, June.

Foray, D. (2013), The economic fundamentals of smart specialisation, Ekonomiaz, Revista vasca de Economía, 83 (2), 83-102.

Foray, D., David, P. \& Hall, B., (2011), Smart Specialization - From academic idea to political instrument, the surprising career of a concept and the difficulties involved in its implementation, Lausanne, MTEI Working Paper, November (Lausanne: Management of Technology and Entrepreneurship Institute).

Frenken, K., Van Oort, F. \& Verburg, T. (2007), Related variety, unrelated variety and regional economic growth, Regional Studies, 41(5): 685-697.

Hidalgo, C. A., Klinger, B., Barabási, A. L. \& Hausmann, R. (2007), The product space conditions the development of nations, Science 317 (5837), 482-487.

Iacobucci, D. (2014), Designing and implementing a smart specialization strategy at regional level: Some open questions, Scienze Regional - Italian Journal of Regional Science, 13(1), 107-126. 
Klepper, S. (2007), Disagreements, spinoffs, and the evolution of Detroit as the capital of the U.S. automobile industry, Management Science, 53: 616-631.

Leten, B., Belderbos, R. \& van Looy, B. (2007), Technological diversification, coherence, and performance of firms, Journal of Product Innovation and Management, 24, 567-579

Maraut, S., Dernis, H., Webb, V., Spiezia, V. \& Guellec, D. (2008), The OECD REGPAT Database: A Presentation, OECD STI Working Papers, 2008/02.

McCann, P. \& Ortega-Argilés. R. (2015), Smart Specialization, Regional Growth and Applications to European Union Cohesion Policy, Regional Studies, 49 (8), 1291-1302.

McCann, P. \& Ortega-Argilés, R. (2016), The early experience of smart specialization implementation in EU cohesion policy, European Planning Studies, 24 (8), 1407-1427.

Montresor, S. and Quatraro, F. (2017), Regional Branching and Key Enabling Technologies: Evidence from European Patent Data, Economic Geography, 93(4):367-396.

Moodysson, J., Trippl, M. \& Zukauskaite, E. (2015), Policy learning and smart specialization: Balancing policy change and policy stability for new regional industrial path development, Papers in Innovation Studies,2015/39.

Neffke, F. (2009), Productive Places: The Influence of Technological Change and Relatedness on Agglomeration Externalities, $\mathrm{PhD}$ thesis, Utrecht University.

Neffke, F., \& Svensson Henning, M. (2008), Revealed relatedness: Mapping industry space, DRUID Working Paper No. 08-18.

OECD (2009), Patents as Statistical Indicators of Science and Technology OECD (2016), REGPAT database, February 2016

Quatraro, F. (2010), Knowledge coherence, variety and economic growth: Manufacturing evidence from Italian regions, Research Policy, 39, 1289-1302

Rigby, D. (2015), Technological Relatedness and Knowledge Space: Entry and Exit of US Cities from Patent Classes, Regional Studies, Vol. 49, No. 11, 1922-1937

Rodriguez-Pose, A. \& Wilkie, C. (2015), Institutions and the entrepreneurial discovery process for smart specialization, Papers in Evolutionary Economic Geography, 15.23. 
Rodrik, D. (2004), Industrial policy for the twenty-first century, working paper, Kennedy School of Management, Harvard University, Cambridge, MA.

Xiao, J., Boschma, R. \& Andersson, M. (2016). Industrial diversification in Europe: The differentiated role of relatedness, Papers in Evolutionary Economic Geography 16.27 
Table 1. Static indicator, by year

\begin{tabular}{c|ccc|ccc}
\hline & \multicolumn{3}{|c|}{ Indicator } & \multicolumn{3}{c}{ Rescaled Indicator } \\
\cline { 2 - 7 } & 1990 & 2000 & 2013 & 1990 & 2000 & 2013 \\
\hline $\mathrm{N}$ & 225 & 258 & 275 & 225 & 258 & 275 \\
mean & 14.69 & 16.11 & 15.32 & 0.39 & 0.42 & 0.43 \\
$\max$ & 36.67 & 38.14 & 34.61 & 1.00 & 1.00 & 1.00 \\
$\min$ & 0.49 & 0.00 & 0.52 & 0.00 & 0.00 & 0.00 \\
std dev & 8.56 & 8.74 & 7.32 & 0.24 & 0.23 & 0.21 \\
\hline
\end{tabular}

Source: author's computations 
Figure 1. Rescaled Static Indicator (1990, 2000, and 2013) - Geographical distribution (left-hand side) and Moran's I statistic (right-hand side)
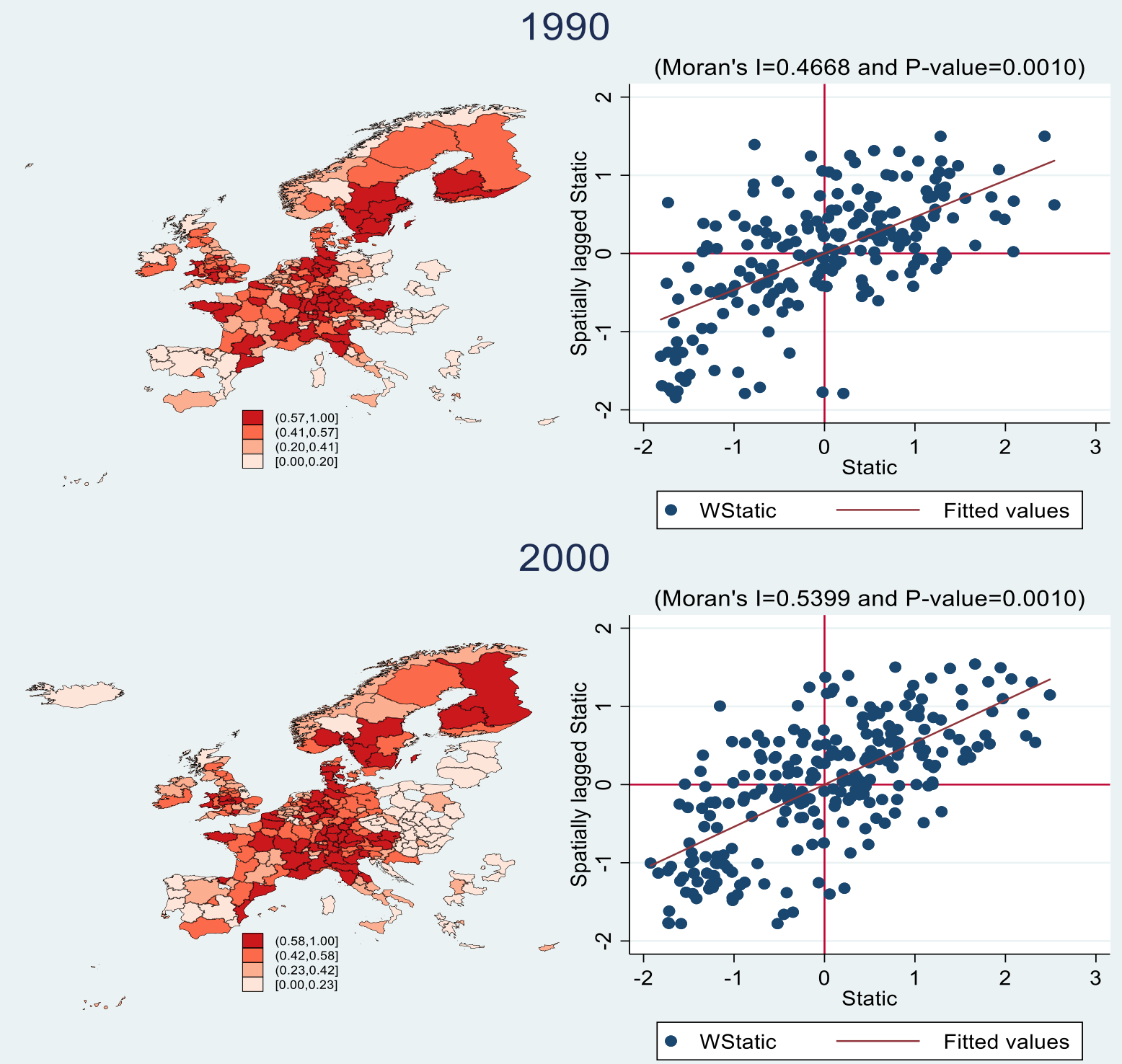

2013
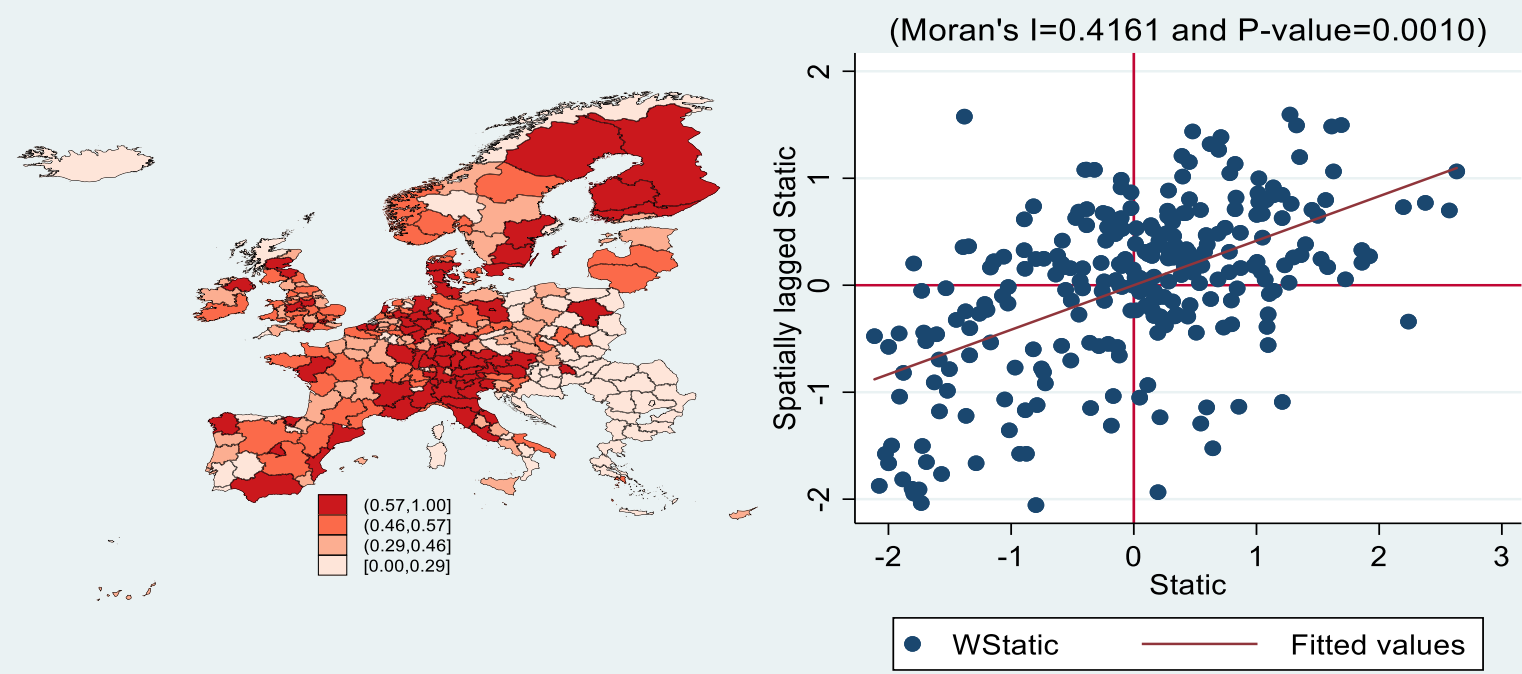

Source: author's computations 
Table 2. Correlation between different sets of variables $(2013,2000 \text {, and 1990 })^{10}$

\begin{tabular}{c|cccccc}
\hline & Patents & Patents pc & GDP pc (PPP) & Competitiveness & Innovation & Institutions \\
\hline N & 758 & 677 & 478 & 235 & 235 & 235 \\
Rescaled Static Indicator & $0.22^{* * *}$ & $0.13^{* * *}$ & $0.45^{* * *}$ & $0.58^{* * *}$ & $0.57^{* * *}$ & $0.51^{* * *}$ \\
\hline
\end{tabular}

$* * *$ Correlation significant at the 0.01 level; $* *$ Correlation significant at the 0.05 level;

*Correlation significant at the 0.1 level

Source: OECD (2016), Eurostat, Annoni \& Dijkstra (2013), and author's computations

\footnotetext{
${ }^{10}$ For GDP pc there are no data for 1990, which explains the lower number of observations when compared to patents. In the case of Regional competitiveness, innovation and quality of institutions indexes the data concern exclusively 2013.
} 
Table 3. Dynamic indicator (2008-2013)

\begin{tabular}{c|c|c}
\hline & Indicator & $\begin{array}{c}\text { Rescaled } \\
\text { Indicator }\end{array}$ \\
\hline $\mathrm{N}$ & 269 & 269 \\
mean & 8.29 & 0.44 \\
max & 18.58 & 1.00 \\
min & 0.33 & 0 \\
std dev & 3.55 & 0.19 \\
\hline
\end{tabular}

Source: author's computations 
Figure 2. Rescaled Dynamic Indicator (2008-2013)

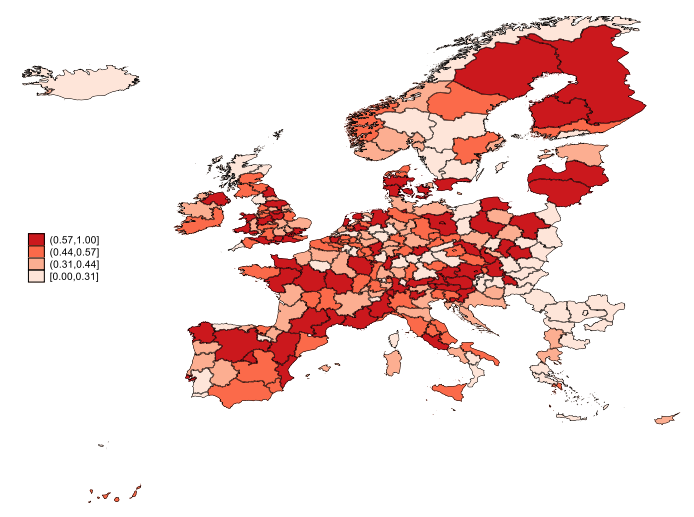

Source: author's computations 
Table 4. Correlation between the Rescaled Dynamic Indicator and the number of technologies with no specialization in 2008.

\begin{tabular}{c|c}
\hline & $\begin{array}{c}\text { N technologies with no } \\
\text { specialization in 2008 }\end{array}$ \\
\hline $\mathrm{N}$ & 269 \\
Rescaled Dynamic Indicator & $-0.45^{* * *}$ \\
\hline
\end{tabular}

***Correlation significant at the 0.01 level; **Correlation significant at the 0.05 level; *Correlation significant at the 0.1 level

Source: author's computations 
Table 5. Average strength of each technology with no specialization in 2008

\begin{tabular}{c|c|c|c}
\hline & N technologies with no specialization in & $\begin{array}{c}\text { Sum of the strength of all technologies } \\
\text { with no specialization in 2008 (1) }\end{array}$ & $\begin{array}{c}\text { Average strength of each technology } \\
\text { with no specialization in 2008 (1/2) }\end{array}$ \\
\hline N & $2008(2)$ & 269 & 269 \\
mean & 97.17 & 49.08 & 0.51 \\
max & 120 & 61 & 0.51 \\
min & 63 & 6.31 & 0.50 \\
std dev & 12.62 & 0.00 & 6 \\
\hline
\end{tabular}

(1) $=\sum_{z} \frac{\text { Rankz }_{\text {it }} \text { NewSpec }_{z i t+5}}{\text { MaxRank }_{i t}}$ as defined in equation (12)

(2) = MaxRank $\mathrm{it}_{\mathrm{it}}$ as defined in equation (9)

Source: author's computations 
Figure 3. Distribution of European regions according to degree of diversity and relatedness in technological areas, 2000 and 2013

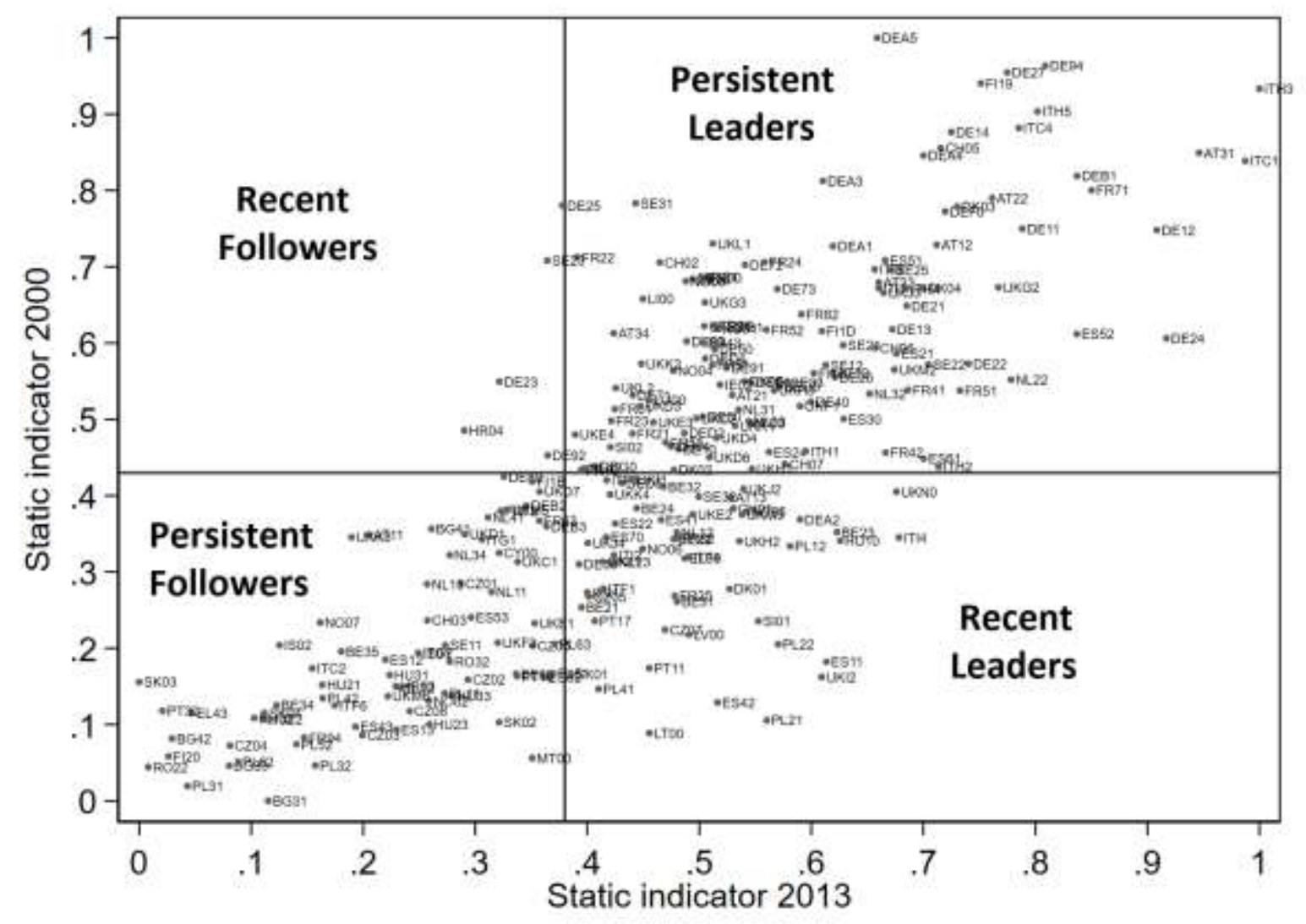

Source: author's computations 


\section{Appendix A - Examples of S3 and the underlying related diversification logic}

\begin{tabular}{|c|c|c|c|c|}
\hline Examples & $\begin{array}{c}\text { Existing } \\
\text { sectors }\end{array}$ & $\begin{array}{l}\text { New emerging } \\
\text { sectors }\end{array}$ & $\begin{array}{c}\text { Activities to be } \\
\text { prioritized }\end{array}$ & $\begin{array}{c}\text { Related } \\
\text { diversification } \\
\text { logic }\end{array}$ \\
\hline $\begin{array}{l}\text { Development of } \\
\text { nanotechnologies for the pulp } \\
\text { and paper industry in Finland }\end{array}$ & $\begin{array}{l}\text { Pulp and paper } \\
\text { industry }\end{array}$ & $\begin{array}{l}\text { Nano- } \\
\text { technologies }\end{array}$ & $\begin{array}{c}\text { Nano-technologies } \\
\text { applied to pulp and paper } \\
\text { industry }\end{array}$ & Modernization \\
\hline $\begin{array}{c}\text { Development of IT } \\
\text { applications for the } \\
\text { management of archaeological } \\
\text { heritage in Italy (Florence) }\end{array}$ & $\begin{array}{l}\text { Exploitation of } \\
\text { archaeological } \\
\text { and historical } \\
\text { heritage }\end{array}$ & IT applications & $\begin{array}{l}\text { IT applications for the } \\
\text { management and } \\
\text { maintenance of } \\
\text { archaeological and } \\
\text { historical heritage }\end{array}$ & Modernization $^{\mathrm{A} 1}$ \\
\hline $\begin{array}{l}\text { Plastics firms diversification } \\
\text { from car industry to } \\
\text { biomedical innovative } \\
\text { applications, in Basque } \\
\text { Country }\end{array}$ & $\begin{array}{l}\text { Plastic sector } \\
\text { applied to car } \\
\text { industry }\end{array}$ & $\begin{array}{l}\text { Plastic sector } \\
\text { applied to } \\
\text { biomedical } \\
\text { applications }\end{array}$ & $\begin{array}{l}\text { Diversification of the } \\
\text { plastic sector towards } \\
\text { biomedical applications }\end{array}$ & Transition \\
\hline $\begin{array}{l}\text { Transition, in Austria, from } \\
\text { fine mechanical and optical } \\
\text { engineering to medical } \\
\text { technologies }\end{array}$ & $\begin{array}{c}\text { Fine } \\
\text { mechanical } \\
\text { and optical } \\
\text { engineering }\end{array}$ & $\begin{array}{c}\text { Medical } \\
\text { technologies }\end{array}$ & $\begin{array}{c}\text { Transition from } \\
\text { mechanical and optical } \\
\text { engineering to medical } \\
\text { technologies }\end{array}$ & Transition \\
\hline $\begin{array}{l}\text { Diversification of automotive } \\
\text { subcontractors from the car } \\
\text { industry to new sectors, in the } \\
\text { British Midlands }\end{array}$ & $\begin{array}{l}\text { Automotive } \\
\text { subcontractors } \\
\text { working for } \\
\text { the car } \\
\text { industry }\end{array}$ & $\begin{array}{l}\text { Automotive } \\
\text { subcontractors } \\
\text { working for } \\
\text { other } \\
\text { industries }\end{array}$ & $\begin{array}{l}\text { Exploring a transition } \\
\text { path for automotive } \\
\text { subcontractors from car } \\
\text { industry towards new } \\
\text { markets }\end{array}$ & Transition \\
\hline $\begin{array}{l}\text { Emergence, in Toulouse, of } \\
\text { entrepreneurial activity in } \\
\text { areas related to satellites and } \\
\text { GPS technologies }\end{array}$ & $\begin{array}{l}\text { Aeronautics } \\
\text { (Airbus) }\end{array}$ & $\begin{array}{l}\text { Satellites and } \\
\text { GPS } \\
\text { technologies }\end{array}$ & $\begin{array}{l}\text { Development of Satellites } \\
\text { and GPS technologies }\end{array}$ & Diversification \\
\hline
\end{tabular}

Source: Foray et al. (2012) and Foray (2013)

\footnotetext{
A1 Although Foray et al. (2012) see this example as a case of 'radical foundation of a new domain', according to the logics of related diversification presented by Foray (2013) it seemed more appropriate to categorize this situation as a case of modernization.
} 
Appendix B - Total number of patent applications per year

\begin{tabular}{rc|cc|cc|cc|cc}
\hline Year & Patents & Year & Patents & Year & Patents & Year & Patents & Year & Patents \\
\hline 1964 & 1 & 1981 & 16260 & 1990 & 31315 & 1999 & 60254 & 2008 & 79072 \\
1966 & 1 & 1982 & 17199 & 1991 & 31305 & 2000 & 65562 & 2009 & 78024 \\
1968 & 1 & 1983 & 19519 & 1992 & 31842 & 2001 & 66182 & 2010 & 79104 \\
1969 & 2 & 1984 & 21266 & 1993 & 33216 & 2002 & 66243 & 2011 & 80388 \\
1975 & 1 & 1985 & 23224 & 1994 & 35271 & 2003 & 68626 & 2012 & 79116 \\
1977 & 2286 & 1986 & 24949 & 1995 & 37216 & 2004 & 72719 & 2013 & 76555 \\
1978 & 7426 & 1987 & 28434 & 1996 & 42999 & 2005 & 75793 & 2014 & 15770 \\
1979 & 11753 & 1988 & 31039 & 1997 & 48775 & 2006 & 79710 & 2015 & 11 \\
\hline
\end{tabular}

Source: OECD (2016) and author's computations 
Appendix C - Total number of patent applications by IPC class and year

\begin{tabular}{|c|c|c|c|c|c|c|c|c|c|}
\hline Year & $\begin{array}{c}\text { Patents } \\
\text { by IPC } \\
\text { class }\end{array}$ & Year & $\begin{array}{l}\text { Patents } \\
\text { by IPC } \\
\text { class }\end{array}$ & Year & $\begin{array}{c}\text { Patents } \\
\text { by IPC } \\
\text { class }\end{array}$ & Year & $\begin{array}{c}\text { Patents } \\
\text { by IPC } \\
\text { class }\end{array}$ & Year & $\begin{array}{c}\text { Patents } \\
\text { by IPC } \\
\text { class }\end{array}$ \\
\hline 1964 & 1 & 1981 & 57546 & 1990 & 118194 & 1999 & 248877 & 2008 & 199285 \\
\hline 1966 & 5 & 1982 & 60976 & 1991 & 121170 & 2000 & 276198 & 2009 & 200434 \\
\hline 1968 & 3 & 1983 & 69610 & 1992 & 121837 & 2001 & 284466 & 2010 & 207914 \\
\hline 1969 & 2 & 1984 & 78454 & 1993 & 128141 & 2002 & 264376 & 2011 & 211595 \\
\hline 1975 & 2 & 1985 & 84223 & 1994 & 137515 & 2003 & 232555 & 2012 & 205630 \\
\hline 1977 & 10691 & 1986 & 92290 & 1995 & 142469 & 2004 & 218491 & 2013 & 200143 \\
\hline 1978 & 29397 & 1987 & 105327 & 1996 & 163162 & 2005 & 187875 & 2014 & 41728 \\
\hline 1979 & 43210 & 1988 & 114214 & 1997 & 183136 & 2006 & 195841 & 2015 & 17 \\
\hline 1980 & 52444 & 1989 & 121474 & 1998 & 209823 & 2007 & 210518 & Total & 5631258 \\
\hline
\end{tabular}

Source: OECD (2016) and author's computations 
Appendix D - Minimum, Median and Maximum by country - Static Indicator

\begin{tabular}{|c|c|c|c|c|c|c|c|c|c|}
\hline \multirow{2}{*}{ Country } & \multicolumn{3}{|c|}{1990} & \multicolumn{3}{|c|}{2000} & \multicolumn{3}{|c|}{2013} \\
\hline & $\min$ & median & $\max$ & $\min$ & median & $\max$ & $\min$ & median & $\max$ \\
\hline Austria & 0.09 & 0.48 & 0.77 & 0.35 & 0.61 & 0.85 & 0.21 & 0.62 & 0.95 \\
\hline Belgium & 0.12 & 0.30 & 0.53 & 0.13 & 0.35 & 0.70 & 0.12 & 0.48 & 0.67 \\
\hline Bulgaria & 0.04 & 0.05 & 0.06 & 0.00 & 0.06 & 0.36 & 0.03 & 0.08 & 0.26 \\
\hline Croatia & 0.04 & 0.04 & 0.04 & 0.15 & 0.32 & 0.49 & 0.23 & 0.26 & 0.29 \\
\hline Cyprus & 0.16 & 0.16 & 0.16 & 0.32 & 0.32 & 0.32 & 0.32 & 0.32 & 0.32 \\
\hline $\begin{array}{c}\text { Czech } \\
\text { Republic }\end{array}$ & 0.13 & 0.13 & 0.13 & 0.07 & 0.18 & 0.28 & 0.08 & 0.29 & 0.47 \\
\hline Denmark & 0.41 & 0.43 & 0.55 & 0.28 & 0.55 & 0.78 & 0.48 & 0.54 & 0.73 \\
\hline Estonia & - & - & - & 0.17 & 0.17 & 0.17 & 0.34 & 0.34 & 0.34 \\
\hline Finland & 0.45 & 0.56 & 0.66 & 0.06 & 0.56 & 0.94 & 0.03 & 0.60 & 0.75 \\
\hline France & 0.00 & 0.55 & 0.72 & 0.08 & 0.51 & 0.80 & 0.04 & 0.48 & 0.85 \\
\hline Germany & 0.07 & 0.57 & 1.00 & 0.31 & 0.59 & 1.00 & 0.32 & 0.57 & 0.92 \\
\hline Greece & 0.04 & 0.07 & 0.31 & 0.04 & 0.11 & 0.32 & 0.02 & 0.07 & 0.49 \\
\hline Hungary & 0.04 & 0.07 & 0.20 & 0.10 & 0.14 & 0.34 & 0.10 & 0.22 & 0.63 \\
\hline Iceland & 0.07 & 0.07 & 0.07 & 0.19 & 0.20 & 0.20 & 0.13 & 0.19 & 0.25 \\
\hline Ireland & 0.01 & 0.24 & 0.46 & 0.27 & 0.41 & 0.55 & 0.40 & 0.46 & 0.52 \\
\hline Italy & 0.02 & 0.34 & 0.90 & 0.13 & 0.44 & 0.93 & 0.07 & 0.55 & 1.00 \\
\hline Latvia & - & - & - & 0.22 & 0.22 & 0.22 & 0.49 & 0.49 & 0.49 \\
\hline Lichtenstein & 0.68 & 0.68 & 0.68 & 0.66 & 0.66 & 0.66 & 0.45 & 0.45 & 0.45 \\
\hline Lithuania & - & - & - & 0.09 & 0.09 & 0.09 & 0.46 & 0.46 & 0.46 \\
\hline Luxembourg & 0.47 & 0.47 & 0.47 & 0.53 & 0.53 & 0.53 & 0.46 & 0.46 & 0.46 \\
\hline Malta & 0.11 & 0.11 & 0.11 & 0.06 & 0.06 & 0.06 & 0.35 & 0.35 & 0.35 \\
\hline Netherlands & 0.14 & 0.40 & 0.66 & 0.27 & 0.40 & 0.69 & 0.26 & 0.45 & 0.78 \\
\hline Norway & 0.11 & 0.29 & 0.46 & 0.13 & 0.38 & 0.68 & 0.16 & 0.48 & 0.54 \\
\hline Poland & 0.00 & 0.04 & 0.07 & 0.02 & 0.14 & 0.33 & 0.04 & 0.18 & 0.58 \\
\hline Portugal & 0.02 & 0.04 & 0.07 & 0.12 & 0.17 & 0.24 & 0.02 & 0.19 & 0.46 \\
\hline Romania & 0.04 & 0.04 & 0.04 & 0.04 & 0.11 & 0.18 & 0.01 & 0.07 & 0.28 \\
\hline Slovakia & 0.04 & 0.04 & 0.04 & 0.10 & 0.14 & 0.17 & 0.00 & 0.22 & 0.39 \\
\hline Slovenia & 0.13 & 0.13 & 0.13 & 0.24 & 0.35 & 0.46 & 0.42 & 0.49 & 0.55 \\
\hline Spain & 0.00 & 0.13 & 0.63 & 0.09 & 0.35 & 0.71 & 0.15 & 0.47 & 0.84 \\
\hline Sweden & 0.51 & 0.62 & 0.70 & 0.20 & 0.57 & 0.78 & 0.27 & 0.54 & 0.70 \\
\hline Switzerland & 0.24 & 0.71 & 0.87 & 0.24 & 0.46 & 0.86 & 0.26 & 0.53 & 0.72 \\
\hline $\begin{array}{l}\text { United } \\
\text { Kingdom }\end{array}$ & 0.12 & 0.44 & 0.67 & 0.14 & 0.44 & 0.73 & 0.19 & 0.50 & 0.77 \\
\hline
\end{tabular}

Source: author's computations 
Appendix E - Percentage of regions, by country, with above-median static indicator (2013)

\begin{tabular}{|c|c|c|c|c|c|c|c|}
\hline Country & $\begin{array}{l}\text { Number of } \\
\text { Regions (\%) }\end{array}$ & Country & $\begin{array}{l}\text { Number of } \\
\text { Regions (\%) }\end{array}$ & Country & $\begin{array}{l}\text { Number of } \\
\text { Regions (\%) }\end{array}$ & Country & $\begin{array}{l}\text { Number of } \\
\text { Regions (\%) }\end{array}$ \\
\hline Bulgaria & $0 \%$ & Portugal & $0 \%$ & Netherlands & $50 \%$ & Sweden & $63 \%$ \\
\hline Croatia & $0 \%$ & Romania & $0 \%$ & Slovenia & $50 \%$ & Belgium & $64 \%$ \\
\hline Cyprus & $0 \%$ & Slovakia & $0 \%$ & Spain & $53 \%$ & Germany & $74 \%$ \\
\hline Estonia & $0 \%$ & Czech Republic & $13 \%$ & United Kingdom & $57 \%$ & Austria & $78 \%$ \\
\hline Iceland & $0 \%$ & Hungary & $14 \%$ & Italy & $57 \%$ & Switzerland & $86 \%$ \\
\hline Lichtenstein & $0 \%$ & Greece & $17 \%$ & Norway & $57 \%$ & Denmark & $100 \%$ \\
\hline Luxembourg & $0 \%$ & Poland & $19 \%$ & Finland & $60 \%$ & Lithuania & $100 \%$ \\
\hline Malta & $0 \%$ & Ireland & $50 \%$ & France & $61 \%$ & Latvia & $100 \%$ \\
\hline
\end{tabular}

Source: author's computations 
Appendix F - Regions by category

\begin{tabular}{|c|c|c|c|}
\hline \multicolumn{4}{|c|}{ S3 Persistent Leaders } \\
\hline Region code & Region name & $\begin{array}{c}\text { Static indicator - } \\
2000\end{array}$ & $\begin{array}{c}\text { Static indicator - } \\
2013\end{array}$ \\
\hline AT12 & NIEDERÖSTERREICH & 0.73 & 0.71 \\
\hline AT21 & KÄRNTEN & 0.53 & 0.53 \\
\hline AT22 & STEIERMARK & 0.79 & 0.76 \\
\hline AT31 & OBERÖSTERREICH & 0.85 & 0.95 \\
\hline AT32 & SALZBURG & 0.56 & 0.62 \\
\hline AT33 & TIROL & 0.68 & 0.66 \\
\hline AT34 & VORARLBERG & 0.61 & 0.42 \\
\hline BE10 & RÉGION DE BRUXELLES-CAPITALE / BRUSSELS HOOFDSTEDELIJK GEWEST & 0.46 & 0.48 \\
\hline BE25 & PROV. WEST-VLAANDEREN & 0.70 & 0.67 \\
\hline BE33 & PROV. LIÈGE & 0.68 & 0.49 \\
\hline $\mathrm{CHO2}$ & ESPACE MITTELLAND & 0.71 & 0.46 \\
\hline $\mathrm{CHO4}$ & ZÜRICH & 0.46 & 0.47 \\
\hline $\mathrm{CH} 05$ & OSTSCHWEIZ & 0.86 & 0.72 \\
\hline $\mathrm{CH} 06$ & ZENTRALSCHWEIZ & 0.59 & 0.66 \\
\hline $\mathrm{CHO7}$ & TICINO & 0.44 & 0.58 \\
\hline DE11 & STUTTGART & 0.75 & 0.79 \\
\hline DE12 & KARLSRUHE & 0.75 & 0.91 \\
\hline DE13 & FREIBURG & 0.62 & 0.67 \\
\hline DE14 & TÜBINGEN & 0.88 & 0.72 \\
\hline DE21 & OBERBAYERN & 0.65 & 0.69 \\
\hline DE22 & NIEDERBAYERN & 0.57 & 0.74 \\
\hline DE24 & OBERFRANKEN & 0.61 & 0.92 \\
\hline DE26 & UNTERFRANKEN & 0.56 & 0.62 \\
\hline DE27 & SCHWABEN & 0.95 & 0.77 \\
\hline DE40 & BRANDENBURG & 0.52 & 0.60 \\
\hline DE50 & BREMEN & 0.59 & 0.51 \\
\hline DE60 & HAMBURG & 0.50 & 0.50 \\
\hline DE71 & DARMSTADT & 0.53 & 0.44 \\
\hline DE72 & GIEßEN & 0.70 & 0.54 \\
\hline DE73 & KASSEL & 0.67 & 0.57 \\
\hline DE91 & BRAUNSCHWEIG & 0.57 & 0.52 \\
\hline DE93 & LÜNEBURG & 0.60 & 0.49 \\
\hline DE94 & WESER-EMS & 0.96 & 0.81 \\
\hline DEA1 & DÜSSELDORF & 0.73 & 0.62 \\
\hline DEA3 & MÜNSTER & 0.81 & 0.61 \\
\hline DEA4 & DETMOLD & 0.85 & 0.70 \\
\hline DEA5 & ARNSBERG & 1.00 & 0.66 \\
\hline DEB1 & KOBLENZ & 0.82 & 0.84 \\
\hline DECO & SAARLAND & 0.54 & 0.57 \\
\hline DED2 & DRESDEN & 0.48 & 0.49 \\
\hline DED4 & CHEMNITZ & 0.58 & 0.51 \\
\hline DEEO & SACHSEN-ANHALT & 0.55 & 0.55 \\
\hline DEFO & SCHLESWIG-HOLSTEIN & 0.77 & 0.72 \\
\hline DEGO & THÜRINGEN & 0.44 & 0.41 \\
\hline DK02 & SJ/ELLAND & 0.43 & 0.48 \\
\hline DK03 & SYDDANMARK & 0.78 & 0.73 \\
\hline DK04 & MIDTJYLLAND & 0.67 & 0.70 \\
\hline DK05 & NORDJYLLAND & 0.55 & 0.54 \\
\hline
\end{tabular}




\begin{tabular}{|c|c|c|c|}
\hline ES21 & PAÍS VASCO & 0.59 & 0.68 \\
\hline ES24 & ARAGÓN & 0.46 & 0.56 \\
\hline ES30 & COMUNIDAD DE MADRID & 0.50 & 0.63 \\
\hline ES51 & CATALUÑA & 0.71 & 0.67 \\
\hline ES52 & COMUNIDAD VALENCIANA & 0.61 & 0.84 \\
\hline ES61 & ANDALUCIA & 0.45 & 0.70 \\
\hline FI19 & LÄNSI-SUOMI & 0.94 & 0.75 \\
\hline FI1C & ETELÄ-SUOMI & 0.56 & 0.60 \\
\hline FI1D & POHJOIS- JA ITÄ-SUOMI & 0.62 & 0.61 \\
\hline FR10 & ÎLE DE FRANCE & 0.43 & 0.39 \\
\hline FR21 & CHAMPAGNE-ARDENNE & 0.48 & 0.44 \\
\hline FR22 & PICARDIE & 0.71 & 0.39 \\
\hline FR23 & HAUTE-NORMANDIE & 0.50 & 0.42 \\
\hline FR24 & CENTRE & 0.71 & 0.56 \\
\hline FR26 & BOURGOGNE & 0.62 & 0.51 \\
\hline FR30 & NORD - PAS-DE-CALAIS & 0.69 & 0.50 \\
\hline FR41 & LORRAINE & 0.54 & 0.69 \\
\hline FR42 & ALSACE & 0.46 & 0.67 \\
\hline FR43 & FRANCHE-COMTÉ & 0.60 & 0.50 \\
\hline FR51 & PAYS DE LA LOIRE & 0.54 & 0.73 \\
\hline FR52 & BRETAGNE & 0.62 & 0.56 \\
\hline FR53 & POITOU-CHARENTES & 0.47 & 0.47 \\
\hline FR61 & AQUITAINE & 0.51 & 0.42 \\
\hline FR71 & RHÔNE-ALPES & 0.80 & 0.85 \\
\hline FR81 & LANGUEDOC-ROUSSILLON & 0.57 & 0.51 \\
\hline FR82 & PROVENCE-ALPES-CÔTE D’AZUR & 0.64 & 0.59 \\
\hline IE02 & SOUTHERN AND EASTERN & 0.55 & 0.52 \\
\hline ITC1 & PIEMONTE & 0.84 & 0.99 \\
\hline ITC3 & LIGURIA & 0.49 & 0.55 \\
\hline ITC4 & LOMBARDIA & 0.88 & 0.79 \\
\hline ITH1 & PROVINCIA AUTONOMA DI BOLZANO/BOZEN & 0.46 & 0.59 \\
\hline ITH2 & PROVINCIA AUTONOMA DI TRENTO & 0.44 & 0.71 \\
\hline ITH3 & VENETO & 0.93 & 1.00 \\
\hline ITH4 & FRIULI-VENEZIA GIULIA & 0.67 & 0.68 \\
\hline ITH5 & EMILIA-ROMAGNA & 0.90 & 0.80 \\
\hline ITI1 & TOSCANA & 0.67 & 0.66 \\
\hline ITI3 & MARCHE & 0.70 & 0.66 \\
\hline LI00 & LIECHTENSTEIN & 0.66 & 0.45 \\
\hline LU00 & LUXEMBOURG (GRAND-DUCHÉ) & 0.53 & 0.46 \\
\hline NL21 & OVERIJSSEL & 0.69 & 0.50 \\
\hline NL22 & GELDERLAND & 0.55 & 0.78 \\
\hline NL31 & UTRECHT & 0.51 & 0.54 \\
\hline NL32 & NOORD-HOLLAND & 0.53 & 0.65 \\
\hline NL33 & ZUID-HOLLAND & 0.50 & 0.54 \\
\hline NL42 & LIMBURG (NL) & 0.44 & 0.40 \\
\hline NO01 & OSLO OG AKERSHUS & 0.62 & 0.52 \\
\hline NO03 & SøR- $\varnothing S T L A N D E T$ & 0.68 & 0.49 \\
\hline NO04 & AGDER OG ROGALAND & 0.56 & 0.48 \\
\hline SE12 & ÖSTRA MELLANSVERIGE & 0.57 & 0.61 \\
\hline SE21 & SMÅLAND MED ÖARNA & 0.60 & 0.63 \\
\hline SE22 & SYDSVERIGE & 0.57 & 0.70 \\
\hline SE31 & NORRA MELLANSVERIGE & 0.78 & 0.44 \\
\hline SE33 & ÖVRE NORRLAND & 0.55 & 0.58 \\
\hline $\mathrm{S} 102$ & ZAHODNA SLOVENIJA & 0.46 & 0.42 \\
\hline
\end{tabular}




$\begin{array}{cccc}\text { UKC2 } & \text { NORTHUMBERLAND AND TYNE AND WEAR } & 0.50 & 0.50 \\ \text { UKD3 } & \text { GREATER MANCHESTER } & 0.52 & 0.45 \\ \text { UKD4 } & \text { LANCASHIRE } & 0.48 & 0.52 \\ \text { UKD6 } & \text { CHESHIRE } & 0.45 & 0.51 \\ \text { UKE3 } & \text { SOUTH YORKSHIRE } & 0.50 & 0.46 \\ \text { UKE4 } & \text { WEST YORKSHIRE } & 0.48 & 0.39 \\ \text { UKF1 } & \text { DERBYSHIRE AND NOTTINGHAMSHIRE } & 0.52 & 0.59 \\ \text { UKF2 } & \text { LEICESTERSHIRE, RUTLAND AND NORTHAMPTONSHIRE } & 0.50 \\ \text { UKG1 } & \text { SHROPSHIRE AND STAFFORDSHIRE } & 0.62 & 0.52 \\ \text { UKG2 } & \text { WEST MIDLANDS } & 0.62 & 0.77 \\ \text { UKG3 } & \text { EAST ANGLIA } & 0.67 & 0.51 \\ \text { UKH1 } & \text { ESSEX } & 0.65 & 0.55 \\ \text { UKH3 } & \text { HAMPSHIRE AND ISLE OF WIGHT } & 0.44 & 0.57 \\ \text { UKJ3 } & \text { DORSET AND SOMERSET } & 0.54 & 0.66 \\ \text { UKK1 } & \text { WEST WALES AND THE VALLEYS } & 0.67 & 0.53 \\ \text { UKK2 } & \text { EAST WALES } & 0.49 & 0.45 \\ \text { UKL1 } & \text { EASTERN SCOTLAND } & 0.57 & 0.51 \\ \text { UKL2 } & \text { GLOUCESTERSHIRE, WILTSHIRE AND BRISTOL/BATH AREA } & 0.73 & 0.43 \\ \text { UKM2 } & \text { WORCESTERSHRE AND WARWICKSHIRE } & 0.54 & 0.67\end{array}$

\begin{tabular}{|c|c|c|c|}
\hline \multicolumn{4}{|c|}{ S3 Recent Leaders } \\
\hline Region code & Region name & $\begin{array}{c}\text { Static indicator - } \\
2000\end{array}$ & $\begin{array}{c}\text { Static indicator - } \\
2013\end{array}$ \\
\hline AT13 & WIEN & 0.40 & 0.53 \\
\hline BE21 & PROV. ANTWERPEN & 0.25 & 0.39 \\
\hline BE22 & PROV. LIMBURG (B) & 0.34 & 0.48 \\
\hline BE23 & PROV. OOST-VLAANDEREN & 0.35 & 0.62 \\
\hline BE24 & PROV. VLAAMS-BRABANT & 0.38 & 0.44 \\
\hline BE31 & PROV. BRABANT WALLON & 0.26 & 0.48 \\
\hline $\mathrm{BE} 32$ & PROV. HAINAUT & 0.41 & 0.47 \\
\hline $\mathrm{CH} 01$ & RÉGION LÉMANIQUE & 0.38 & 0.53 \\
\hline CZ05 & SEVEROVYCHOD & 0.27 & 0.40 \\
\hline CZO7 & STREDNI MORAVA & 0.22 & 0.47 \\
\hline DE30 & BERLIN & 0.31 & 0.39 \\
\hline DEA2 & KÖLN & 0.37 & 0.59 \\
\hline DED5 & LEIPZIG & 0.42 & 0.43 \\
\hline DK01 & HOVEDSTADEN & 0.28 & 0.53 \\
\hline EL30 & ATTIKI & 0.32 & 0.49 \\
\hline ES11 & GALICIA & 0.18 & 0.61 \\
\hline ES22 & COMUNIDAD FORAL DE NAVARRA & 0.36 & 0.42 \\
\hline ES41 & CASTILLA Y LEÓN & 0.37 & 0.47 \\
\hline ES42 & CASTILLA-LA MANCHA & 0.13 & 0.52 \\
\hline ES70 & CANARIAS & 0.35 & 0.42 \\
\hline FR25 & BASSE-NORMANDIE & 0.27 & 0.48 \\
\hline FR62 & MIDI-PYRÉNÉES & 0.34 & 0.48 \\
\hline HU10 & KOZEP-MAGYARORSZAG & 0.34 & 0.63 \\
\hline IE01 & BORDER, MIDLAND AND WESTERN & 0.27 & 0.40 \\
\hline ITF1 & ABRUZZO & 0.28 & 0.41 \\
\hline ITF3 & CAMPANIA & 0.42 & 0.42 \\
\hline ITF4 & PUGLIA & 0.32 & 0.49 \\
\hline $\mathrm{ITI}$ & UMBRIA & 0.32 & 0.42 \\
\hline ITI4 & LAZIO & 0.35 & 0.68 \\
\hline LTOO & LIETUVA & 0.09 & 0.46 \\
\hline LV00 & LATVIJA & 0.22 & 0.49 \\
\hline
\end{tabular}




$\begin{array}{cccc}\text { NL12 } & \text { FRIESLAND (NL) } & 0.35 & 0.48 \\ \text { NL23 } & \text { FLEVOLAND } & 0.31 & 0.42 \\ \text { NO05 } & \text { VESTLANDET } & 0.38 & 0.54 \\ \text { NO06 } & \text { TRøNDELAG } & 0.33 & 0.45 \\ \text { PL12 } & \text { MAZOWIECKIE } & 0.33 & 0.58 \\ \text { PL21 } & \text { MALOPOLSKIE } & 0.11 & 0.56 \\ \text { PL22 } & \text { SLASKIE } & 0.21 & 0.57 \\ \text { PL41 } & \text { WIELKOPOLSKIE } & 0.41 \\ \text { PT11 } & \text { NORTE } & 0.15 & 0.46 \\ \text { PT17 } & \text { LISBOA } & 0.17 & 0.41 \\ \text { SE32 } & \text { MELLERSTA NORRLAND } & 0.50 \\ \text { SI01 } & \text { VZHODNA SLOVENIJA } & 0.24 & 0.55 \\ \text { SK01 } & \text { BRATISLAVSKY KRAJ } & 0.40 & 0.39 \\ \text { UKE2 } & \text { NORTH YORKSHIRE } & 0.24 & 0.49 \\ \text { UKH2 } & \text { BEDFORDSHIRE AND HERTFORDSHIRE } & 0.17 & 0.54 \\ \text { UKI1 } & \text { INNER LONDON } & 0.38 & 0.44 \\ \text { UKI2 } & \text { OUTER LONDON } & 0.34 & 0.61 \\ \text { UKJ1 } & \text { BERKSHIRE, BUCKINGHAMSHIRE AND OXFORDSHIRE } & 0.42 & 0.41 \\ \text { UKJ2 } & \text { SURREY, EAST AND WEST SUSSEX } & 0.16 & 0.54 \\ \text { UKJ4 } & \text { KENT } & 0.31 & 0.40 \\ \text { UKK4 } & \text { DEVON } & 0.41 & 0.42 \\ \text { UKM3 } & \text { S3 Persistent Followers } & 0.34 & 0.54 \\ \text { UKN0 } & \text { SOUTH WESTERN SCOTLAND } & 0.40 & 0.68 \\ & \text { NORTHERN IRELAND } & 0.38 & 0.41 \\ \end{array}$

\begin{tabular}{|c|c|c|c|}
\hline Region code & Region name & $\begin{array}{l}\text { Static indicator - } \\
2000\end{array}$ & $\begin{array}{c}\text { Static indicator } \\
2013\end{array}$ \\
\hline AT11 & BURGENLAND (A) & 0.35 & 0.21 \\
\hline BE34 & PROV. LUXEMBOURG (B) & 0.13 & 0.12 \\
\hline BE35 & PROV. NAMUR & 0.20 & 0.18 \\
\hline BG31 & SEVEROZAPADEN & 0.00 & 0.12 \\
\hline BG33 & SEVEROIZTOCHEN & 0.05 & 0.08 \\
\hline BG41 & YUGOZAPADEN & 0.36 & 0.26 \\
\hline BG42 & YUZHEN TSENTRALEN & 0.08 & 0.03 \\
\hline $\mathrm{CH} 03$ & NORDWESTSCHWEIZ & 0.24 & 0.26 \\
\hline CYOO & KYPROS / KIBRIS & 0.32 & 0.32 \\
\hline CZO1 & PRAHA & 0.28 & 0.29 \\
\hline CZO2 & STREDNI CECHY & 0.16 & 0.29 \\
\hline CZO3 & JIHOZAPAD & 0.09 & 0.20 \\
\hline CZO4 & SEVEROZAPAD & 0.07 & 0.08 \\
\hline CZO6 & JIHOVYCHOD & 0.20 & 0.35 \\
\hline CZO8 & MORAVSKOSLEZSKO & 0.12 & 0.24 \\
\hline DE80 & MECKLENBURG-VORPOMMERN & 0.42 & 0.33 \\
\hline DEB2 & TRIER & 0.39 & 0.35 \\
\hline DEB3 & RHEINHESSEN-PFALZ & 0.36 & 0.36 \\
\hline EEOO & EESTI & 0.17 & 0.34 \\
\hline EL12 & KENTRIKI MAKEDONIA & 0.15 & 0.23 \\
\hline EL43 & KRITI & 0.11 & 0.05 \\
\hline ES12 & PRINCIPADO DE ASTURIAS & 0.19 & 0.22 \\
\hline ES13 & CANTABRIA & 0.09 & 0.23 \\
\hline ES43 & EXTREMADURA & 0.10 & 0.19 \\
\hline ES53 & ILLES BALEARS & 0.24 & 0.30 \\
\hline ES62 & REGIÓN DE MURCIA & 0.16 & 0.36 \\
\hline $\mathrm{FI} 1 \mathrm{~B}$ & HELSINKI-UUSIMAA & 0.42 & 0.35 \\
\hline
\end{tabular}




\begin{tabular}{|c|c|c|c|}
\hline $\mathrm{FI} 20$ & ÅLAND & 0.06 & 0.03 \\
\hline FR63 & LIMOUSIN & 0.37 & 0.36 \\
\hline FR72 & AUVERGNE & 0.38 & 0.32 \\
\hline FR94 & RÉUNION & 0.08 & 0.15 \\
\hline HRO3 & JADRANSKA HRVATSKA & 0.15 & 0.23 \\
\hline HU21 & KOZEP-DUNANTUL & 0.15 & 0.16 \\
\hline HU22 & NYUGAT-DUNANTUL & 0.11 & 0.11 \\
\hline HU23 & DEL-DUNANTUL & 0.10 & 0.26 \\
\hline HU31 & ESZAK-MAGYARORSZAG & 0.17 & 0.22 \\
\hline HU32 & ESZAK-ALFOLD & 0.11 & 0.10 \\
\hline HU33 & DEL-ALFOLD & 0.14 & 0.28 \\
\hline ISO1 & CAPITAL REGION & 0.19 & 0.25 \\
\hline ISO2 & OTHER REGIONS & 0.20 & 0.13 \\
\hline ITC2 & VALLE D’AOSTA/VALLÉE D’AOSTE & 0.17 & 0.15 \\
\hline ITF6 & CALABRIA & 0.13 & 0.17 \\
\hline ITG1 & SICILIA & 0.34 & 0.31 \\
\hline ITG2 & SARDEGNA & 0.19 & 0.25 \\
\hline Мт00 & MALTA & 0.06 & 0.35 \\
\hline NL11 & GRONINGEN & 0.27 & 0.31 \\
\hline NL13 & DRENTHE & 0.28 & 0.26 \\
\hline NL34 & ZEELAND & 0.32 & 0.28 \\
\hline NL41 & NOORD-BRABANT & 0.37 & 0.31 \\
\hline NO02 & HEDMARK OG OPPLAND & 0.13 & 0.26 \\
\hline NO07 & NORD-NORGE & 0.23 & 0.16 \\
\hline PL11 & LODZKIE & 0.14 & 0.27 \\
\hline PL31 & LUBELSKIE & 0.02 & 0.04 \\
\hline PL32 & PODKARPACKIE & 0.05 & 0.16 \\
\hline PL42 & ZACHODNIOPOMORSKIE & 0.13 & 0.16 \\
\hline PL51 & DOLNOSLASKIE & 0.17 & 0.37 \\
\hline PL52 & OPOLSKIE & 0.07 & 0.14 \\
\hline PL62 & WARMINSKO-MAZURSKIE & 0.05 & 0.09 \\
\hline PL63 & POMORSKIE & 0.21 & 0.37 \\
\hline PT16 & CENTRO (P) & 0.16 & 0.34 \\
\hline РT30 & REGIÃO AUTONOMA DA MADEIRA & 0.12 & 0.02 \\
\hline $\mathrm{RO} 22$ & SUD-EST & 0.04 & 0.01 \\
\hline RO32 & BUCURESTI - ILFOV & 0.18 & 0.28 \\
\hline SE11 & STOCKHOLM & 0.20 & 0.27 \\
\hline SK02 & ZAPADNE SLOVENSKO & 0.10 & 0.32 \\
\hline SK03 & STREDNE SLOVENSKO & 0.16 & 0.00 \\
\hline SK04 & VYCHODNE SLOVENSKO & 0.11 & 0.11 \\
\hline UKC1 & TEES VALLEY AND DURHAM & 0.31 & 0.34 \\
\hline UKD1 & CUMBRIA & 0.35 & 0.29 \\
\hline UKD7 & MERSEYSIDE & 0.41 & 0.36 \\
\hline UKE1 & EAST YORKSHIRE AND NORTHERN LINCOLNSHIRE & 0.23 & 0.35 \\
\hline UKF3 & LINCOLNSHIRE & 0.21 & 0.32 \\
\hline UKK3 & CORNWALL AND ISLES OF SCILLY & 0.35 & 0.19 \\
\hline UKM5 & NORTH EASTERN SCOTLAND & 0.38 & 0.33 \\
\hline UKM6 & HIGHLANDS AND ISLANDS & 0.14 & 0.22 \\
\hline
\end{tabular}

S3 Recent Followers

\begin{tabular}{cccc}
\hline \multirow{2}{*}{ Region code } & \multirow{2}{*}{ Region name } & Static indicator - & \multicolumn{2}{c}{ Static indicator - } \\
& & $\mathbf{2 0 0 0}$ & $\mathbf{2 0 1 3}$ \\
\hline DE23 & OBERPFALZ & 0.55 & 0.32 \\
DE25 & MITTELFRANKEN & 0.78 & 0.38
\end{tabular}


Appendix G - Percentage distribution of regions according to categories, by country

\begin{tabular}{|c|c|c|c|c|c|}
\hline Countries & $\begin{array}{l}\text { S3 peristent } \\
\text { leaders }\end{array}$ & $\begin{array}{l}\text { S3 recent } \\
\text { leaders }\end{array}$ & $\begin{array}{l}\text { S3 persistent } \\
\text { followers }\end{array}$ & $\begin{array}{l}\text { S3 recent } \\
\text { followers }\end{array}$ & $\mathrm{N}$ regions \\
\hline Austria & $78 \%$ & $11 \%$ & $11 \%$ & $0 \%$ & 9 \\
\hline Belgium & $27 \%$ & $55 \%$ & $18 \%$ & $0 \%$ & 11 \\
\hline Bulgaria & $0 \%$ & $0 \%$ & $100 \%$ & $0 \%$ & 4 \\
\hline Croatia & $0 \%$ & $0 \%$ & $50 \%$ & $50 \%$ & 2 \\
\hline Cyprus & $0 \%$ & $0 \%$ & $100 \%$ & $0 \%$ & 1 \\
\hline Czech Republic & $0 \%$ & $25 \%$ & $75 \%$ & $0 \%$ & 8 \\
\hline Denmark & $80 \%$ & $20 \%$ & $0 \%$ & $0 \%$ & 5 \\
\hline Estonia & $0 \%$ & $0 \%$ & $100 \%$ & $0 \%$ & 1 \\
\hline Finland & $60 \%$ & $0 \%$ & $40 \%$ & $0 \%$ & 5 \\
\hline France & $77 \%$ & $9 \%$ & $14 \%$ & $0 \%$ & 22 \\
\hline Germany & $76 \%$ & $8 \%$ & $8 \%$ & $8 \%$ & 38 \\
\hline Greece & $0 \%$ & $33 \%$ & $67 \%$ & $0 \%$ & 3 \\
\hline Hungary & $0 \%$ & $14 \%$ & $86 \%$ & $0 \%$ & 7 \\
\hline Iceland & $0 \%$ & $0 \%$ & $100 \%$ & $0 \%$ & 2 \\
\hline Ireland & $50 \%$ & $50 \%$ & $0 \%$ & $0 \%$ & 2 \\
\hline Italy & $53 \%$ & $26 \%$ & $21 \%$ & $0 \%$ & 19 \\
\hline Latvia & $0 \%$ & $100 \%$ & $0 \%$ & $0 \%$ & 1 \\
\hline Lichtenstein & $100 \%$ & $0 \%$ & $0 \%$ & $0 \%$ & 1 \\
\hline Lithuania & $0 \%$ & $100 \%$ & $0 \%$ & $0 \%$ & 1 \\
\hline Luxembourg & $100 \%$ & $0 \%$ & $0 \%$ & $0 \%$ & 1 \\
\hline Malta & $0 \%$ & $0 \%$ & $100 \%$ & $0 \%$ & 1 \\
\hline Netherlands & $50 \%$ & $17 \%$ & $33 \%$ & $0 \%$ & 12 \\
\hline Norway & $43 \%$ & $29 \%$ & $29 \%$ & $0 \%$ & 7 \\
\hline Poland & $0 \%$ & $33 \%$ & $67 \%$ & $0 \%$ & 12 \\
\hline Portugal & $0 \%$ & $50 \%$ & $50 \%$ & $0 \%$ & 4 \\
\hline Romania & $0 \%$ & $0 \%$ & $100 \%$ & $0 \%$ & 2 \\
\hline Slovakia & $0 \%$ & $25 \%$ & $75 \%$ & $0 \%$ & 4 \\
\hline Slovenia & $50 \%$ & $50 \%$ & $0 \%$ & $0 \%$ & 2 \\
\hline Spain & $38 \%$ & $31 \%$ & $31 \%$ & $0 \%$ & 16 \\
\hline Sweden & $63 \%$ & $13 \%$ & $13 \%$ & $13 \%$ & 8 \\
\hline Switzerland & $71 \%$ & $14 \%$ & $14 \%$ & $0 \%$ & 7 \\
\hline United Kingdom & $51 \%$ & $27 \%$ & $22 \%$ & $0 \%$ & 37 \\
\hline
\end{tabular}

Source: author's computations 